\title{
Production of cecropin A in transgenic rice plants has an impact on host gene expression
}

\author{
Sonia Campo', Silvia Manrique1, José García-Martínez² and Blanca San Segundo1,* \\ ${ }^{1}$ Consorcio CSIC-IRTA Laboratorio de Genética Molecular Vegetal, Departamento de Genética Molecular, Instituto de Biología Molecular de Barcelona, CSIC, Jordi \\ Girona 18, 08034 Barcelona, Spain \\ ${ }^{2}$ Laboratori de Chips de DNA, S.C.S.I.E., Universitat de València, Dr. Moliner, 50, 46100 Burjassot, Valencia, Spain
}

Received 23 November 2007; revised 26 February 2008; accepted 12 March 2008 *Correspondence (fax 3493 2045904; e-mail bssgmb@cid.csic.es)
Keywords: blast, cecropin, endoplasmic reticulum, macroarray, Oryza sativa, oxidative stress, plant defence.

\begin{abstract}
Summary
Expression of the cecropin $A$ gene in rice confers resistance to the rice blast fungus Magnaporthe oryzae. In this study, a polymerase chain reaction-based suppression subtractive hybridization approach was used to generate a cDNA macroarray from the elite japonica rice (Oryza sativa L.) cultivar 'Senia'. Gene expression studies revealed that the expression of components of the protein secretory and vesicular transport machinery is coordinately activated at the pre-invasive stage of infection of rice by the blast fungus. Comparisons of gene expression between wild-type and cecropin A plants revealed the over-expression of genes involved in protection against oxidative stress in transgenic plants in the absence of the pathogen, which correlated well with the tolerance of these plants to oxidative stress. A subcellular fractionation analysis suggested that cecropin $A$ accumulates in the endoplasmic reticulum in cecropin $A$ rice. Moreover, a large number of genes related to the processes of synthesis, folding and stabilization of proteins that enter into the secretory pathway are over-expressed in cecropin $A$ rice, confirming that these plants constitutively express the unfolded protein response. Transgenic expression of cecropin $A$ in rice has an effect on the transcriptional reprogramming that accompanies plant adaptation to fungal infection. Overall, this study provides evidence for transgene-induced changes in gene expression in cecropin $A$ rice under both optimal growth conditions and stress conditions imposed by fungal infection. The data also indicate that resistance to blast in cecropin $A$ rice may be the consequence of a combination of the antifungal activity of cecropin A and cecropin A-mediated over-expression of rice genes.
\end{abstract}

\section{Introduction}

Plant diseases caused by pathogens are responsible for huge annual losses in cultivated crops. Rice blast, caused by the fungus Magnaporthe oryzae (Hebert) Barr (anamorph Pyricularia grisea Saccardo), is one of the most devastating diseases of cultivated rice (Oryza sativa) worldwide (Ou, 1985). Rice blast infections are initiated by the spores of M. oryzae, which are spread by splash dispersal and adhere tightly to the rice leaf cuticle. The spores germinate quickly and, within $8 \mathrm{~h}$, each can form a specialized infection structure, called an 'appressorium'. This fungus has been described as a hemibiotrophic pathogen that maintains an initial biotrophic relationship with its host (Talbot, 2003). The biotrophic stage of the rice- $M$. oryzae interaction is critical for the establishment of pathogenesis, and determines whether or not the pathogen will be successful in its colonization attempts. After the initial asymptomatic phase, which lasts for up to 3 days, $M$. oryzae causes large, necrotic disease lesions on rice leaves. In severe cases, the fungus can cause the whole seedling to die, whereas, in older plants, it can prevent grain filling or destroy the grain-bearing structures of the plant (Talbot, 2003). Breeding for durable resistance to this fungus seems to be difficult because of the 
highly dynamic manner in which the blast pathogen population responds to a resistant rice cultivar. Fungicides are commonly used to control blast. However, the repeated use of hazardous agrochemicals for the control of this disease has several drawbacks, such as their lack of specificity, increased incidence of the development of resistance on prolonged application and the adverse impact on human health and the environment. The development of rice cultivars with durable resistance is one of the main objectives in rice breeding programmes. In this respect, plant genetic engineering provides an opportunity to introduce genes conferring resistance to the rice blast fungus into cultivated rice varieties.

Different genetic strategies have been used to generate disease-resistant plants, including the utilization of antimicrobial genes of both plant and non-plant origin (Broglie et al., 1991; Lorito et al., 1998; Datta et al., 1999). The outcome has varied, but the resistance obtained on introduction of a single plant antifungal gene, i.e. chitinase or $\beta$-1,3-glucanase gene, does not support the production of new diseaseresistant varieties suitable for commercial agriculture. One of the main limitations is the relatively low level of resistance and the narrow spectrum of protection obtained with a single plant antimicrobial gene. In contrast, the expression of genes encoding antimicrobial peptides of animal, fungal or bacterial origin in transgenic plants has been proven to confer high levels of protection and a broad spectrum of resistance against pathogens (Lorito et al., 1998; Emani et al., 2003; Coca et al., 2004; de las Mercedes Dana et al., 2006). No negative effects on plant phenotype have been observed in many of these disease-resistant transgenic plants. However, the expression of foreign genes in transgenic plants may potentially lead to alterations in endogenous gene activities that are not detected during the phenotypic or agronomic evaluation of transgenic plants. Although the benefits of transgenic approaches in enhancing protection against pathogens have been repeatedly demonstrated, a deeper understanding of the potential changes in host gene expression that may be induced by transgenesis is still lacking. Equally, studies to determine whether the transgenic expression of an antimicrobial gene affects the natural inducible plant defence responses under infection conditions are needed. The information gained will be very important in adding to our understanding of 'substantial equivalence' between transgenic and wild-type plants.

Recently, the stable transformation of an elite japonica rice (O. sativa L. CV. 'Senia') with a plant codon-optimized synthetic cecropin $A$ gene from the Cecropia moth, Hyalophora cecropia, has been reported (Coca et al., 2006). Constitutive expression of the cecropin $A$ gene in rice confers high levels of protection against the rice blast fungus $M$. oryzae. The expression of the synthetic cecropin $A$ gene is stable for at least four generations, and does not cause any effect on plant phenotype when grown under controlled glasshouse conditions. In this work, the possibility of cecropin A-induced alterations in host gene expression is explored. Our research objectives were twofold: (i) to determine whether transgenic expression of the cecropin $A$ gene has an impact in the host plant, in terms of gene expression, under non-infection conditions; and (ii) to investigate whether transgenic expression of cecropin $A$ has an effect on the pathogeninducible rice defence response during interaction of the transgenic plant with the blast fungus. To accomplish these objectives, a polymerase chain reaction-based suppression subtractive hybridization (PCR-SSH) approach was used to construct a cDNA library from the rice cultivar Senia (cultivar used for the transgenic expression of the cecropin $A$ gene; Coca et al., 2006). This CDNA library was employed to fabricate a rice macroarray containing 6144 rice expressed sequence tags (ESTs), which was then used in studies of gene expression in both transgenic and non-transgenic rice plants under optimal growth conditions and under stress conditions imposed by fungal infection. Evidence for transgene-induced changes in endogenous gene activities in cecropin $A$ rice plants is reported.

\section{Results}

In order to investigate whether transgenic expression of the cecropin $A$ gene in rice has an effect on host gene expression, the response of rice plants to $M$. oryzae infection was characterized. This study was carried out in the japonica rice cultivar Senia. Although many reports in the literature have described the induction of rice genes in response to infection by the rice blast fungus, most of these studies have been conducted at the colonization stage of the rice-M. oryzae interaction (necrotrophic lifestyle) (Kim et al., 2001; Rauyaree et al., 2001; Xiong et al., 2001; Lu et al., 2004). In this work, the rice response was investigated at the early stages of the rice-blast interaction, namely at the pre-invasion stage. To accomplish our objective, a PCR-SSH approach in combination with CDNA macroarray technology was used for the identification of genes that are up-regulated during the very early phases of the rice-blast interaction (3-48 h). The macroarray containing the subtracted CDNA library was then used in comparative analyses of gene expression between cecropin $A$ and wild-type plants under normal growth conditions, as well as during the interaction of the transgenic plants with the rice blast fungus. 


\section{Construction of the rice subtracted library and macroarray analysis}

The PCR-SSH Senia library was obtained by the subtraction of cDNA populations derived from $M$. oryzae-infected leaves from the cDNA representing uninfected leaves from Senia plants. Leaf tissues were collected at 3, 6, 9, 24 and $48 \mathrm{~h}$ after inoculation with $M$. oryzae spores. For each time point, leaf tissues from control, mock-inoculated leaves were also collected. Tester (samples of infected leaves) and driver (samples from control, non-infected leaves) cDNAs were prepared from a pool of at least three independent RNA preparations for each condition. Before using the RNA samples for the construction of the subtracted library, the expression of the PR1a gene, a widely used indicator for the induction of plant defence responses, was confirmed (results not shown). Two rounds of SSH were carried out to construct the fungal-induced, transcript-enriched library. Following PCR amplification of CDNA inserts, the PCR products were checked by agarose gel electrophoresis (results not shown). The average insert size was approximately $450 \mathrm{bp}$, ranging from 150 to $800 \mathrm{bp}$. A total of 6144 cDNA inserts, or ESTs, representing independent clones of the subtractive library and the internal controls of the macroarray, were spotted on to nylon membranes using robotic printing.

Differential gene expression was assessed by hybridizing the macroarray with ${ }^{33} \mathrm{P}$-labelled cDNAs prepared from RNAs obtained from either non-infected or $M$. oryzae-infected rice leaves at 3 and 6 h after inoculation with fungal spores. Gene expression data at $48 \mathrm{~h}$ after infection were also obtained to assess the expression of marker genes or the rice response to blast infection. Thus, pair-wise comparisons were performed in which each fungal-infected condition (3, 6 or 48 h) was compared with each non-infected condition (3, 6 or 48 h). Two independent cDNA preparations and two replica membranes were made for each infection time. After scanning and global normalization, the signal intensity and expression ratio (infected vs. non-infected) were determined.

\section{Identification of genes differentially expressed at the pre-invasive stage of rice infection with the rice blast fungus}

Based on the differential screening of the 6144 ESTs arrayed in the rice macroarray, 590 ESTs showing an expression ratio equal to or greater than two (infected vs. non-infected) in one or more of the three comparisons $[3,6$ or $48 \mathrm{~h}$ postinoculation (pi)] were identified. None gave a positive signal on hybridization of the macroarray with a ${ }^{33} \mathrm{P}$-labelled genomic

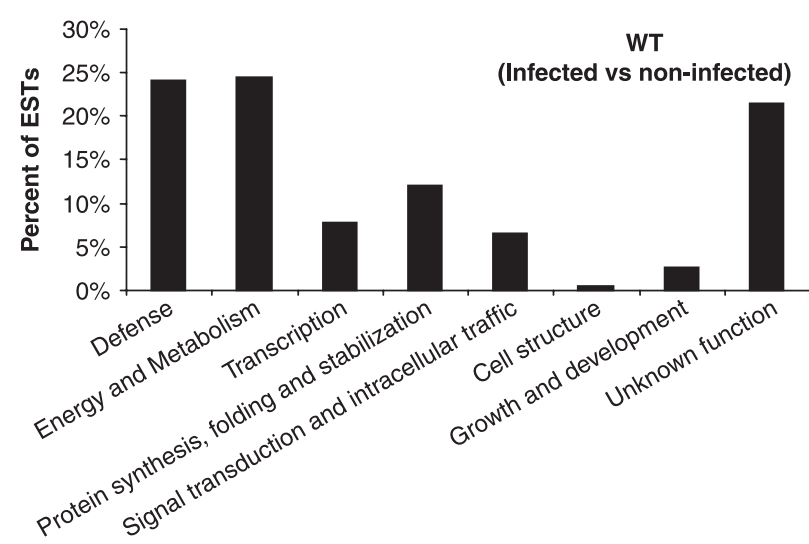

Figure 1 Functional classification of rice expressed sequence tags (ESTs) that are up-regulated in response to infection by the blast fungus Magnaporthe oryzae in wild-type rice plants (cv. Senia). The $y$-axis indicates the percentage of ESTs grouped in each category. Unigenes were categorized using the GENBANK and KOME databases.

DNA from $M$. oryzae (results not shown). Nucleotide sequence analysis of 331 of the 590 ESTs showing differential expression generated 162 unique genes which were grouped into eight gene functional categories: (i) defence; (ii) energy and metabolism; (iii) transcription; (iv) protein synthesis, folding and stabilization; (v) signal transduction and intracellular traffic; (vi) cell structure; (vii) growth and development; and (viii) unclassified or unknown function (Figure 1; Table 1). The largest sets of ESTs were assigned to the categories of energy and metabolism, and disease/defence $(24.5 \%$ and $24.2 \%$, respectively). Some of the ESTs identified by differential screening were redundant, redundancy being defined as the presence of either several cDNA fragments corresponding to a particular gene, or several copies of a given cDNA fragment for that gene. Redundancy found in each functional category varied greatly, with the highest percentage of redundancy found in the defence and metabolism categories. Genes with most ESTs most probably represent genes that are abundantly expressed during $M$. oryzae infection and/or genes that are up-regulated at the various times of infection used for the construction of the subtracted library. Of the 162 unique genes showing differential expression, 142 unique genes were transcriptionally activated as early as 3-6 h after inoculation.

The defence gene category accounted for $24.2 \%$ of the differentially expressed ESTs encoding proteins that are considered to be part of the general plant defence response as they are induced in many different plant-pathogen systems (Table 1). Several pathogenesis-related $(P R)$ genes, such as PR1, $\beta$-1,3-glucanase, thaumatin-like protein, cysteine proteinase inhibitor, PR10 and lipid transfer protein genes, 
Table 1 Rice genes up-regulated by Magnaporthe oryzae infection, sorted according to functional category

\begin{tabular}{|c|c|c|c|}
\hline Description* & Accession numbert & Number of ESTs $\neq$ & Expression ratio§ \\
\hline \multicolumn{4}{|l|}{ 1. Disease/defence } \\
\hline Ascorbate peroxidase (APX), thylakoid-bound & AB114856 & 4 & $2.7(3 \mathrm{~h})$ \\
\hline$\beta$-1,3-glucanase & AK098943 & 1 & $3.0(48$ h) \\
\hline Carbonic anhydrase 3 & AF182806 & 4 & $4.1(3 \mathrm{~h}), 2.0(48 \mathrm{~h})$ \\
\hline Catalase isozyme $A$ & X61626 & 1 & $3.2(3 \mathrm{~h})$ \\
\hline Copper chaperone homologue & AP008214 & 1 & $2.4(3 \mathrm{~h}), 2.7(48 \mathrm{~h})$ \\
\hline Cysteine proteinase inhibitor & AK119511 & 1 & $2.2(3 h)$ \\
\hline Defender against apoptotic death 1 protein (DAD1) & D89727 & 1 & $4.4(3 h)$ \\
\hline Glycolate oxidase & AF022740 & 1 & $2.1(3 \mathrm{~h})$ \\
\hline Glyoxalase I & AB017042 & 1 & $2.7(3 \mathrm{~h})$ \\
\hline Glycine-rich protein (GRP 0.9) & $\times 54449$ & 30 & $3.1(3 h), 2.1$ (6 h), 2.6 (48 h) \\
\hline Lipid transfer protein (LTPIV) & AK070414 & 1 & $2.3(3 \mathrm{~h})$ \\
\hline Lipid transfer protein precursor (LTP2) & U31766 & 2 & $2.0(3 \mathrm{~h}), 2.7(6 \mathrm{~h})$ \\
\hline Lipid transfer protein, b1 & X83434 & 6 & $2.3(6 \mathrm{~h})$ \\
\hline Metallothionein-like type 1 (OsMT1) & U43529 & 2 & $2.0(48 h)$ \\
\hline Oryzacystatin (cysteine protease inhibitor) & S49967 & 6 & $2.5(3 \mathrm{~h}), 2.4(6 \mathrm{~h}), 2.2$ (48 h) \\
\hline Pathogenesis-related protein 1 (PR1) & AF306651 & 1 & $2.3(48 \mathrm{~h})$ \\
\hline Pathogenesis-related protein class 1 (PRb1) & AY339373 & 1 & $2.4(48 h)$ \\
\hline Pathogenesis-related protein 10 (OSPR10), root specific & $A B 127580$ & 1 & $6.3(48 \mathrm{~h})$ \\
\hline Peroxidase (POX8.1) & AF014468 & 6 & $2.3(6 \mathrm{~h}), 2.7(48 \mathrm{~h})$ \\
\hline Peroxiredoxin & AK059845 & 1 & $2.3(3 \mathrm{~h})$ \\
\hline Planthopper susceptibility protein Hd002A & AK066843 & 1 & $6.4(3 \mathrm{~h})$ \\
\hline Protein, similar to CMV 1a interacting protein 1/tobacco & AK059127 & 1 & $2.1(3 h)$ \\
\hline $\begin{array}{l}\text { Iron stress-related protein (RIS9), similar to a } \\
\text { Citrus junos clone } p B C R 9\end{array}$ & AK120252 & 1 & $2.8(6 \mathrm{~h})$ \\
\hline Thaumatin-like protein & X68197 & 2 & $2.0(3 \mathrm{~h}), 2.7(6 \mathrm{~h}), 4.5(48 \mathrm{~h})$ \\
\hline Thioredoxin $f 2$ protein & AK101264 & 3 & $3.0(3 \mathrm{~h}), 2.0(6 \mathrm{~h})$ \\
\hline Water stress-induced protein (WSI724) & D26538 & 1 & $2.3(6 \mathrm{~h})$ \\
\hline Wound-induced protein homologue IAI2 & AB059238 & 1 & $3.4(3 \mathrm{~h}), 2.0(48 \mathrm{~h})$ \\
\hline \multicolumn{4}{|l|}{ 2. Energy and metabolism } \\
\hline 23-kDa polypeptide of photosystem II & AF052203 & 2 & $2.1(6 h), 2.6(48 h)$ \\
\hline 33-kDa oxygen-evolving protein of photosystem II & AK119515 & 2 & $2.9(3 \mathrm{~h}), 2.3(6 \mathrm{~h})$ \\
\hline Adenylosuccinate synthetase & AK120407 & 1 & $2.3(3 \mathrm{~h})$ \\
\hline Aspartate kinase-homoserine dehydrogenase & AK073790 & 1 & $2.7(3 \mathrm{~h})$ \\
\hline ATP-dependent Clp protease ATP-binding subunit precursor (CLPD1) & AY166599 & 1 & $2.6(48 \mathrm{~h})$ \\
\hline Chlorophyll a/b-binding protein (RCABP69) & AF058796 & 1 & $2.3(3 \mathrm{~h})$ \\
\hline Chlorophyll a/b-binding protein precursor (Cab26) & AF094776 & 1 & $2.0(6 \mathrm{~h})$ \\
\hline Cytidine or deoxycytidylate deaminase & AK100710 & 1 & $2.0(6 h)$ \\
\hline Cytochrome P450 & AK104799 & 1 & $2.2(48 \mathrm{~h})$ \\
\hline Farnesyl-pyrophosphate synthetase & AP008210 & 1 & $2.0(48 \mathrm{~h})$ \\
\hline Ferredoxin-dependent glutamate synthase & Y12595 & 2 & $2.1(3 \mathrm{~h})$ \\
\hline Fructose-bisphosphate aldolase class-I & AF017362 & 1 & $3.7(3 \mathrm{~h})$ \\
\hline Glyceraldehyde-3-phosphate dehydrogenase & U31676 & 1 & $5.1(3 \mathrm{~h})$ \\
\hline Hydrolase, $\alpha / \beta$ fold family protein & AK070827 & 1 & $2.2(6 \mathrm{~h})$ \\
\hline Hydroxyanthranilate hydroxycinnamoyltransferase & AK119237 & 1 & $2.0(6 \mathrm{~h})$ \\
\hline $\begin{array}{l}\text { Magnesium-chelatase subunit H (Mg-protoporphyrin IX } \\
\text { chelatase subunit H) }\end{array}$ & AK069545 & 2 & $2.0(3 \mathrm{~h})$ \\
\hline $\begin{array}{l}\text { Magnesium-protoporphyrin IX monomethyl ester (oxidative) } \\
\text { cyclase, chloroplast precursor }\end{array}$ & AK069333 & 1 & $2.0(6 \mathrm{~h})$ \\
\hline Malate dehydrogenase, cytoplasmic & AF353203 & 1 & $3.2(48 h)$ \\
\hline NADP-specific isocitrate dehydrogenase & AF155333 & 1 & $2.5(3 \mathrm{~h})$ \\
\hline NOL1/NOP2/sun family protein, putative methyltransferase & AK073815 & 1 & $2.4(6 \mathrm{~h})$ \\
\hline Phosphoglycerate kinase, chloroplast precursor & AK062214 & 3 & $2.0(3 \mathrm{~h}), 2.2(6 \mathrm{~h})$ \\
\hline Phosphoglycerate mutase family protein, putative & AK068167 & 1 & $2.5(3 h)$ \\
\hline Phosphoribulokinase precursor & AF529237 & 1 & $2.8(6 \mathrm{~h})$ \\
\hline
\end{tabular}


Table 1 (Continued)

\begin{tabular}{|c|c|c|c|}
\hline Description* & Accession numbert & Number of ESTs $\neq$ & Expression ratio§ \\
\hline Phosphoserine aminotransferase, chloroplast precursor & AK109385 & 1 & $2.3(6 \mathrm{~h})$ \\
\hline Photosystem I reaction centre subunit IV & AP008213 & 2 & $2.2(3 \mathrm{~h}), 2.1(48 \mathrm{~h})$ \\
\hline Photosystem I/ 10-kDa polypeptide & AK121083 & 8 & $5.4(3 \mathrm{~h}), 2.6(48 \mathrm{~h})$ \\
\hline Photosystem I antenna protein & AK105002 & 1 & $2.3(3 \mathrm{~h})$ \\
\hline Photosystem I antenna protein & AK119176 & 1 & $2.0(48 \mathrm{~h})$ \\
\hline Ribulose-1,5-bisphosphate carboxylase/oxygenase small subunit & AK070257 & 9 & $2.6(3 \mathrm{~h})$ \\
\hline Ribulose-1,5-bisphosphate carboxylase/oxygenase small subunit & AY445627 & 16 & $3.1(3 \mathrm{~h})$ \\
\hline Ribulose-1,5-bisphosphate carboxylase/oxygenase small subunit & D00643 & 1 & $7.1(3 \mathrm{~h})$ \\
\hline Ribulose-5-phosphate-3-epimerase & AK066306 & 2 & $7.8(3 h), 4.4(6 h), 2.0(48 h)$ \\
\hline Ribulose-5-phosphate-3-epimerase & AF047444 & 1 & $4.0(3 \mathrm{~h})$ \\
\hline S-Adenosyl methionine synthetase (pRSAM-1) & Z26867 & 1 & $2.9(6 \mathrm{~h})$ \\
\hline Triose-phosphate isomerase & AK069488 & 1 & $2.9(3 \mathrm{~h})$ \\
\hline $\begin{array}{l}\text { Type I light-harvesting chlorophyll a/b binding protein of photosystem } \\
\text { II (LHCPII) }\end{array}$ & D00641 & 5 & $2.3(6 h), 2.9(48 h)$ \\
\hline $\begin{array}{l}\text { Ubiquinol-cytochrome c reductase complex ubiquinone-binding } \\
\text { protein }\end{array}$ & AK120341 & 1 & $2.0(6 \mathrm{~h})$ \\
\hline UGP mRNA for UDP-glucose pyrophosphorylase & AB062606 & 1 & $2.8(3 \mathrm{~h})$ \\
\hline \multicolumn{4}{|l|}{ 3. Transcription } \\
\hline $\begin{array}{l}\text { AP2 domain-containing transcription factor, similar to DNA-binding } \\
\quad \text { protein RAV2 }\end{array}$ & AK065008 & 1 & $3.2(48$ h) \\
\hline Basic helix-loop-helix (bHLH) family protein & AK073385 & 5 & $3.3(3 h), 2.1(6 h), 2.1(48 h)$ \\
\hline Basic helix-loop-helix (bHLH) family protein & AP008207 & 4 & $3.0(3 \mathrm{~h}), 2.0(6 \mathrm{~h})$ \\
\hline $\begin{array}{l}\text { Ethylene-responsive element binding protein (EREBP)-type } \\
\text { transcription factor }\end{array}$ & AF364176 & 1 & $2.4(6 \mathrm{~h})$ \\
\hline Glycine-rich RNA-binding protein (grp5 gene) & AJ302060 & 1 & $2.1(48 h)$ \\
\hline Glycine-rich RNA-binding protein & AF011331 & 1 & $7.6(3 \mathrm{~h})$ \\
\hline Nuclear RNA-binding protein & AK121001 & 1 & $3.2(3 h)$ \\
\hline Plastid sigma factor $2 B$, OsSig $2 B$ & AB095095 & 1 & $2.6(3 \mathrm{~h})$ \\
\hline RNA-binding protein homologue & AK060161 & 1 & $5.0(3 \mathrm{~h})$ \\
\hline RNA helicase $\mathrm{RH} 25$ & AK067570 & 1 & $2.0(3 \mathrm{~h})$ \\
\hline RNA helicase & AK101403 & 1 & $2.1(6 \mathrm{~h})$ \\
\hline $\begin{array}{l}\text { RNA recognition motif ( } R R M \text { )-containing protein, low similarity to } \\
\quad R N A \text {-binding protein } R G P-3\end{array}$ & AK070704 & 1 & $3.3(3 \mathrm{~h})$ \\
\hline $\begin{array}{l}\text { Splicing factor, putative strong similarity to splicing factor Prp8 } \\
\text { (Homo sapiens) }\end{array}$ & AK099780 & 1 & $2.4(6 \mathrm{~h})$ \\
\hline Transcription factor-like & AK059092 & 1 & $2.4(6 \mathrm{~h})$ \\
\hline U2 snRNP auxiliary factor, small subunit 35a & Y18349 & 1 & $2.8(6 \mathrm{~h})$ \\
\hline Zinc finger protein (Tranpr) & AY574990 & 2 & $3.4(3 \mathrm{~h})$ \\
\hline Zinc finger transcription factor & AK100770 & 2 & $3.2(3 h)$ \\
\hline \multicolumn{4}{|l|}{ 4. Protein synthesis, folding and stabilization } \\
\hline Acidic ribosomal protein $P 2$ gene & D29689 & 1 & $2.4(6 \mathrm{~h})$ \\
\hline Aspartic proteinase Asp1 precursor (OsAsp1) (nucellin-like protein) & AK068664 & 1 & $2.4(6 \mathrm{~h})$ \\
\hline$\beta 5$ subunit of 205 proteasome (OsPBE1) & AB026568 & 1 & $2.0(3 \mathrm{~h})$ \\
\hline Cyclophilin 2 & L29469 & 1 & $2.0(6 \mathrm{~h})$ \\
\hline Eukaryotic translation initiation factor 5A-2 (elF5A-2) & AK099039 & 1 & $2.1(6 \mathrm{~h})$ \\
\hline Eukaryotic translation initiation factor 5 A (elF5A) & AJ312906 & 1 & $2.0(3 \mathrm{~h}), 2.7(48 \mathrm{~h})$ \\
\hline Heat shock protein 90 (HSP90) & AB037681 & 2 & $2.0(48 h)$ \\
\hline Plastid-specific 305 ribosomal protein 1, chloroplast precursor & AK104733 & 5 & $2.4(3 \mathrm{~h}), 2.1(6 \mathrm{~h})$ \\
\hline Protein disulphide isomerase (PDI) & AY987391 & 1 & $2.4(3 \mathrm{~h})$ \\
\hline Protein disulphide isomerase (PDI) & AY224470 & 1 & $2.0(3 \mathrm{~h})$ \\
\hline Signal peptidase $1-1$ & AK069581 & 1 & $3.1(3 \mathrm{~h})$ \\
\hline 405 ribosomal protein $515 a$ & AK240912 & 1 & $3.3(48$ h) \\
\hline $40 S$ ribosomal protein $\mathrm{S3a}$ (cyc07 protein) & D26060 & 1 & $2.1(6 \mathrm{~h})$ \\
\hline 405 ribosomal protein 58 & AK068316 & 1 & $3.3(3 \mathrm{~h})$ \\
\hline
\end{tabular}


Table 1 (Continued)

\begin{tabular}{|c|c|c|c|}
\hline Description* & Accession numbert & Number of ESTs‡ & Expression ratio§ \\
\hline $40 S$ ribosomal protein $\$ 21$ & D12633 & 2 & $2.0(3 \mathrm{~h})$ \\
\hline $40 S$ ribosomal protein S23 (S12) & AK069399 & 1 & $2.7(3 \mathrm{~h})$ \\
\hline $60 S$ ribosomal protein $L 35$ & AK119701 & 1 & $2.0(6 \mathrm{~h})$ \\
\hline $60 S$ ribosomal protein $\angle 35 a$ & AK102775 & 1 & $2.0(6 \mathrm{~h})$ \\
\hline $60 S$ ribosomal protein $L 37 a$ & AK059395 & 1 & $2.2(6 \mathrm{~h})$ \\
\hline Ribosomal protein $L 17$ & AK120273 & 1 & $4.3(3 \mathrm{~h})$ \\
\hline Ribosomal protein $\mathrm{S} 13$ ( $x d 3$ gene) & AJ417519 & 1 & $3.3(3 \mathrm{~h})$ \\
\hline Ribosomal protein 527 & AK059683 & 1 & $7.1(3 \mathrm{~h})$ \\
\hline Translation elongation factor $1 \alpha(E F-1 \alpha)$ & D63580 & 2 & $3.3(3 \mathrm{~h})$ \\
\hline Translation elongation factor $1 \alpha(E F-1 \alpha)$ & D63581 & 1 & $2.0(6 \mathrm{~h})$ \\
\hline Translation elongation factor $1 \alpha(E F-1 \alpha)$ & D63583 & 1 & $2.3(3 \mathrm{~h}), 3.0(6 \mathrm{~h})$ \\
\hline Translation elongation factor $1 \beta(E F-1 \beta)$ & D23674 & 1 & $3.3(3 \mathrm{~h})$ \\
\hline Threonyl-tRNA synthetase & Y14368 & 1 & $2.0(3 \mathrm{~h})$ \\
\hline Threonyl-tRNA synthetase & AK058738 & 1 & $3.1(3 \mathrm{~h})$ \\
\hline Ubiquitin/ribosomal protein \$27a.1 & AK061988 & 2 & $4.2(3 \mathrm{~h}), 2.8(6 \mathrm{~h}), 2.0(48 \mathrm{~h})$ \\
\hline Ubiquitin-conjugating enzyme family protein & AK119659 & 1 & $2.0(6 \mathrm{~h})$ \\
\hline Ubiquitin-like protein & AK058725 & 2 & $3.4(3 \mathrm{~h})$ \\
\hline \multicolumn{4}{|l|}{ 5. Signal transduction and intracellular traffic } \\
\hline Aquaporin & AK119719 & 1 & $2.0(6 \mathrm{~h})$ \\
\hline BR/1-KDa interacting protein 102 (Bip102) & AB117990 & 1 & $8.1(6 \mathrm{~h})$ \\
\hline BRI1-KDa interacting protein 128 (Bip128) & AK066179 & 1 & $4.1(3 \mathrm{~h})$ \\
\hline GTPase activating-like protein (GAP) & AK099843 & 1 & $2.1(6 \mathrm{~h})$ \\
\hline Mitogen-activated protein kinase (MAPK) phosphatase & AK067768 & 1 & $2.4(3 \mathrm{~h})$ \\
\hline Plasma membrane $\mathrm{H}^{+}$-ATPase-like protein & AY224445 & 1 & $4.3(3 \mathrm{~h})$ \\
\hline Profilin & AK121519 & 1 & $2.1(48 \mathrm{~h})$ \\
\hline Protein kinase-like protein & AK065283 & 1 & $2.5(3 \mathrm{~h})$ \\
\hline Ras-related GTP-binding protein (Rgp1) & X59276 & 1 & $2.0(6 \mathrm{~h})$ \\
\hline Receptor-like protein kinase (DUF26-like) & AY847141 & 2 & $2.1(6 h), 2.6(48 h)$ \\
\hline Remorin 1 & AK106182 & 3 & $7.4(3 \mathrm{~h})$ \\
\hline $\begin{array}{l}\text { SIT4 phosphatase-associated family protein contains similarity to } \\
\text { copper chaperone homologue }\end{array}$ & AK067338 & 1 & $2.0(6 \mathrm{~h}), 2.0(48 \mathrm{~h})$ \\
\hline Snf1-related protein kinase (OSK1) & D82039 & 1 & $4.2(3 \mathrm{~h})$ \\
\hline Tonoplast intrinsic protein (OsTIP1) & AB114829 & 1 & $2.0(6 \mathrm{~h})$ \\
\hline Transport protein particle (TRAPP) Bet3 component & AK111377 & 2 & $2.1(3 \mathrm{~h}), 6.1(48 \mathrm{~h})$ \\
\hline Vacuolar proton-translocating ATPase subunit E & AK071200 & 1 & $7.1(3 \mathrm{~h})$ \\
\hline Vesicle transport v-SNARE & AK104463 & 1 & $2.9(3 \mathrm{~h}), 2.2(6 \mathrm{~h})$ \\
\hline Voltage-dependent anion channel (VDAC) porin & AK100231 & 1 & $2.7(3 \mathrm{~h}), 2.0(6 \mathrm{~h})$ \\
\hline \multicolumn{4}{|l|}{ 6. Cell structure } \\
\hline Chloroplast inner envelope protein & AK120578 & 1 & $2.0(3 \mathrm{~h})$ \\
\hline Inner mitochondrial membrane protein & AK103851 & 1 & $2.3(6 \mathrm{~h})$ \\
\hline \multicolumn{4}{|l|}{ 7. Growth and division } \\
\hline Auxin responsive protein, IAA1 & AJ251791 & 1 & $4.0(6 \mathrm{~h})$ \\
\hline$D N A$ repair protein, $R A D 23-3$ & AK061556 & 1 & $2.5(48 h)$ \\
\hline Dormancy-associated protein, auxin repressed & AF467730 & 2 & $2.5(6 h), 2.8(48 h)$ \\
\hline Light-induced protein & X68807 & 4 & $2.2(3 \mathrm{~h}), 36.2(48 \mathrm{~h})$ \\
\hline Senescence-associated protein, OSA15 & AY037805 & 1 & $2.2(6 \mathrm{~h})$ \\
\hline \multicolumn{4}{|l|}{ 8. Unclassified or unknown function } \\
\hline $\begin{array}{l}\text { 33-kDa secretory protein (DUF26 domain containing protein } \\
2 \text { precursor) }\end{array}$ & AK061425 & 4 & $2.1(3 \mathrm{~h}), 2.0(6 \mathrm{~h}), 2.4(48 \mathrm{~h})$ \\
\hline Anther-specific proline-rich protein APG precursor & AK066367 & 1 & $2.5(3 \mathrm{~h}), 2.6(48 \mathrm{~h})$ \\
\hline Expressed protein contains 1 transmembrane domain & AK121047 & 1 & $2.0(6 \mathrm{~h})$ \\
\hline Expressed protein & AK065040 & 1 & $3.0(3 \mathrm{~h})$ \\
\hline Expressed protein & AK068443 & 1 & $13.4(3 \mathrm{~h})$ \\
\hline
\end{tabular}


Table 1 (Continued)

\begin{tabular}{|c|c|c|c|}
\hline Description* & Accession numbert & Number of ESTs $\ddagger$ & Expression ratio§ \\
\hline Expressed protein & AK068661 & 18 & $3.2(3 \mathrm{~h}), 2.3(6 \mathrm{~h}), 3.1$ (48 h) \\
\hline Expressed protein & AK121344 & 1 & $4.0(3 \mathrm{~h})$ \\
\hline Expressed protein & XM_463125 & 2 & $2.8(3 \mathrm{~h}), 2.0(6 \mathrm{~h}), 3.1(48 \mathrm{~h})$ \\
\hline Genomic sequence & AP008212 & 2 & $2.6(3 \mathrm{~h}), 2.4(6 \mathrm{~h})$ \\
\hline Genomic sequence & AP008213 & 22 & $2.9(3 h), 2.2(6 h), 2.6(48 h)$ \\
\hline Genomic sequence & AP008218 & 1 & $3.0(6 h)$ \\
\hline Hypothetical protein & $A B 110171$ & 1 & $2.6(3 h)$ \\
\hline Hypothetical protein & AK105731 & 1 & $2.0(6 \mathrm{~h})$ \\
\hline Pentatricopeptide $(P P R)$ repeat-containing protein & AP008217 & 1 & $2.4(3 \mathrm{~h}), 2.2(6 \mathrm{~h})$ \\
\hline Reticulon family protein (RTNLB2) & AK073583 & 1 & $2.2(3 \mathrm{~h})$ \\
\hline TMS membrane protein/tumour differentially expressed protein (TDE) & AK119191 & 1 & $3.8(3 \mathrm{~h})$ \\
\hline Unknown protein & AK059554 & 1 & $2.0(3 \mathrm{~h})$ \\
\hline Unknown protein & AK099155 & 1 & $2.2(3 \mathrm{~h}), 2.0(48 \mathrm{~h})$ \\
\hline Unknown protein & AK103517 & 1 & $2.5(48 \mathrm{~h})$ \\
\hline Unknown protein & AK104019 & 1 & $2.2(48 \mathrm{~h})$ \\
\hline Unknown protein & AK119691 & 1 & $3.2(48 h)$ \\
\hline Unknown protein & AK120355 & 1 & $2.5(3 \mathrm{~h})$ \\
\hline Unknown protein & NM_186253 & 6 & $2.5(3 \mathrm{~h}), 2.3(6 \mathrm{~h}), 2.0(48 \mathrm{~h})$ \\
\hline
\end{tabular}

*Unigenes for which the transcript level was up-regulated are listed by functional category according to the Munich Information Centre for Protein Sequences (MIPS, http://mips.gsf.de). Only genes showing a ratio of $\geq 2.0$ (infected vs. non-infected) are listed.

†Accession numbers for unigenes (GENBANK and KOME databases).

¥Number of expressed sequence tag (EST) components in each gene is indicated.

$\S$ Expression ratio: signal intensity ratio of infected leaves over control, non-infected leaves of wild-type plants. The time of infection at which up-regulation was observed is shown in parentheses.

were up-regulated in rice leaves in response to $M$. oryzae infection. A carbonic anhydrase also showed fungal responsiveness in rice leaves. Genes encoding wound, water and iron stress-induced proteins were also up-regulated in fungal-infected rice leaves. In this respect, it is well known that a substantial number of genes display a common response to various types of stress, biotic and abiotic (Reymond et al., 2000). In addition, our macroarray data revealed that the expression of genes encoding enzymes involved in tolerance against oxidative stress and the detoxification of reactive oxygen species (ROS), such as catalase, peroxidase POX8.1, ascorbate peroxidase, peroxiredoxin, thioredoxin and metallothionein, was induced in the early response of rice plants to $M$. oryzae infection. The defence category also included the DAD1 (Defender against Apoptotic Death 1) gene; this gene encodes an enzyme that performs the $\mathrm{N}$-linked protein glycosylation required for protein transport from the endoplasmic reticulum (ER) to the target site of action. A suppressor activity in programmed cell death has been proposed for the Arabidopsis DAD1 gene (Danon et al., 2004).

The functional category of energy and metabolism contained a large number of ESTs (24.5\% of the ESTs). These included genes involved in photosynthesis and carbohydrate metabolism (fructose-bisphosphate aldolase, glyceraldehyde3-phosphate dehydrogenase and phosphoglycerate kinase). This observation further supports a link between photosynthesis and carbohydrate metabolism and the plant defence response.

The functional category of protein synthesis, folding and stabilization comprised $12.1 \%$ of the ESTs (31 unique genes) showing pathogen responsiveness. Blast infection was accompanied by the up-regulation of components of the translational machinery, including the genes encoding translation initiation factor $5 \mathrm{~A}$ (elF5A, two genes), elongation factors $1 \alpha$ and $1 \beta$ (EF-1 $\alpha$ and EF- $1 \beta$ ) and 13 ribosomal proteins, pointing to the occurrence of active protein synthesis during the pre-invasive defence response of rice. This study also revealed that the expression of genes encoding proteins involved in protein modification, folding and stabilization, such as signal peptidase $1-1$, protein disulphide isomerase (PDI), heat shock protein 90 (HSP90) and cyclophilin, was rapidly induced in response to $M$. oryzae infection.

Transcription and RNA modification (RNA-binding proteins, RNA helicases and the splicing factor Prp8, amongst others) accounted for $7.9 \%$ of the ESTs showing fungal responsiveness. In particular, macroarray analysis revealed the induction of transcription factors for which a role in 
disease resistance has been described in other pathosystems, such as the ethylene-responsive factor [ethylene-responsive element binding protein (EREBP)-type] and the basic helix-loop-helix (bHLH)-type transcription factor (BerrocalLobo et al., 2002; Gutterson and Reuber, 2004).

Finally, $6.7 \%$ of the fungal-responsive ESTs identified in this work were categorized into the signal transduction and intracellular traffic category. Interestingly, genes that were upregulated at the early stages of infection included several components of the vesicle-associated transport machinery, such as genes encoding the vesicle (v)-soluble $\mathrm{N}$-ethylmaleimidesensitive factor (NSF) attachment protein receptor ( $v$ SNARE) protein, the Ras-related guanosine triphosphate (GTP)-binding protein and the guanosine triphosphatase (GTPase)-activating protein or a transport protein particle (TRAPP). Additional genes encoding signalling components or regulatory proteins potentially involved in the early response of rice plants to $M$. oryzae were also expressed: genes encoding remorin, specific protein kinases and protein phosphatases, aquaporin, voltage-dependent anion channel (VDAC) porin, plasma membrane $\mathrm{H}^{+}$-ATPase, vacuolar proton-translocating ATPase (subunit $\mathrm{E}$ ), tonoplast intrinsic OsTIP1 protein, Bip102 and Bip128 (BRI1-kDa interacting protein 102 and 128, respectively).

\section{Time course of transcript accumulation of selected $M$. oryzae-induced rice genes}

To validate and extend the macroarray data, the time course of transcript accumulation for several randomly selected up-regulated genes was monitored further. Depending on the relative abundance of these transcripts, Northern blot, reverse transcriptase-polymerase chain reaction (RT-PCR) and real-time quantitative RT-PCR ( $q R T-P C R$ ) analyses were carried out (Figure 2). Most of the genes analysed here were induced at early time points of the infection period (4-6 h after inoculation). After this initial response, a decline in the expression of many of these genes was observed (Figure 2a). A second peak of fungal-induced expression occurred at later stages of the infection process (32-48 $\mathrm{h}$ pi), as observed for the PR1a, $\beta$-1,3-glucanase, TLP and PR10 genes (Figure 2a). Changes in the level of expression of genes involved in the early response of rice plants to blast fungus (6h, $9 h$ ), such as Ras-related GTP-binding protein (Rgp1) and GTPaseactivating protein (GAP) genes, and genes activated at a later stage of the infection process ( $24 \mathrm{~h}, 48 \mathrm{~h}$ ), such as TRAPP-Bet3 and profilin genes, were detected by RT-PCR (Figure 2b). Finally, changes in the level of expression of genes encoding EREBP, elF5A and HSP90 were confirmed by
qRT-PCR analysis (Figure 2c). Except for the classical $P R$ genes, the expression studies of many of the selected upregulated rice genes required the application of RT-PCR or qRT-PCR techniques, indicating that the PCR-SSH procedure successfully enriched low-abundance, fungal-responsive genes. Overall, these expression studies corroborated the results observed by macroarray analysis, and confirmed that the subtracted library reliably represents fungal-induced genes from rice.

\section{Comparative analysis of gene expression in cecropin $A$ and wild-type rice}

The macroarray was used to investigate whether transgenic expression of the cecropin A gene induced changes in gene expression in the host plant when grown under optimal conditions (i.e. glasshouse-grown plants). The transgenic cecropin A rice lines analysed here express a codon-optimized synthetic cecropin A gene from $\mathrm{H}$. cecropia under the control of the constitutive maize ubiquitin 1 promoter (Coca et al., 2006). The cecropin A gene was designed for retention of cecropin A in the ER (Coca et al., 2006). For this, the signal peptide of the tobacco PR1a gene and the KDEL extension for retention in the ER were fused at the $\mathrm{N}$ - and C-terminus, respectively, of the mature cecropin $A$.

Macroarray hybridizations were conducted with cDNAs generated from leaves of 2 -week-old cecropin $A$ and wild-type plants. Leaves from three independent transgenic lines (R33-6, R33-7 and R33-24) and 10 individual plants per line were pooled. Two replica membranes were hybridized with each CDNA probe. One hundred and sixty-eight unique genes were identified as being over-expressed in cecropin $A$ plants using an arbitrary cut-off of 2.5-fold, and were grouped into the different functional categories (Figure 3a). A description of the genes that were over-expressed in cecropin A plants, and the extent of variation of their expression compared with wild-type plants, is shown in Table 2. An important number of these genes were found to be expressed at high levels in cecropin $A$ plants compared with wild-type plants in the absence of infection. Thus, 58 of the 168 unigenes showed fourfold expression in transgenic plants.

An important result of this study was the observation that genes encoding enzymes involved in protection against oxidative stress, such as peroxidases (three distinct genes), glutathione-S-transferase, iron superoxide dismutase and the metallothionein OsMT1, were highly expressed in cecropin A plants in the absence of $M$. oryzae infection. These genes represented up to $44.44 \%$ of the genes categorized in the defence category (Table 2). Comparison of the gene expression 
(a)

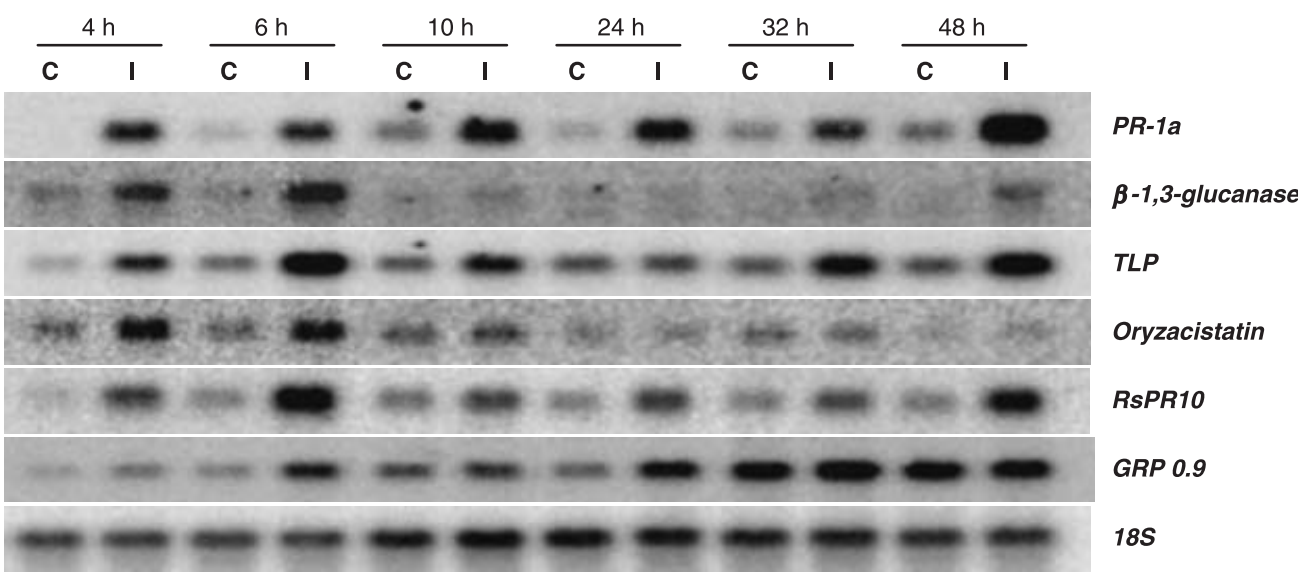

(b)
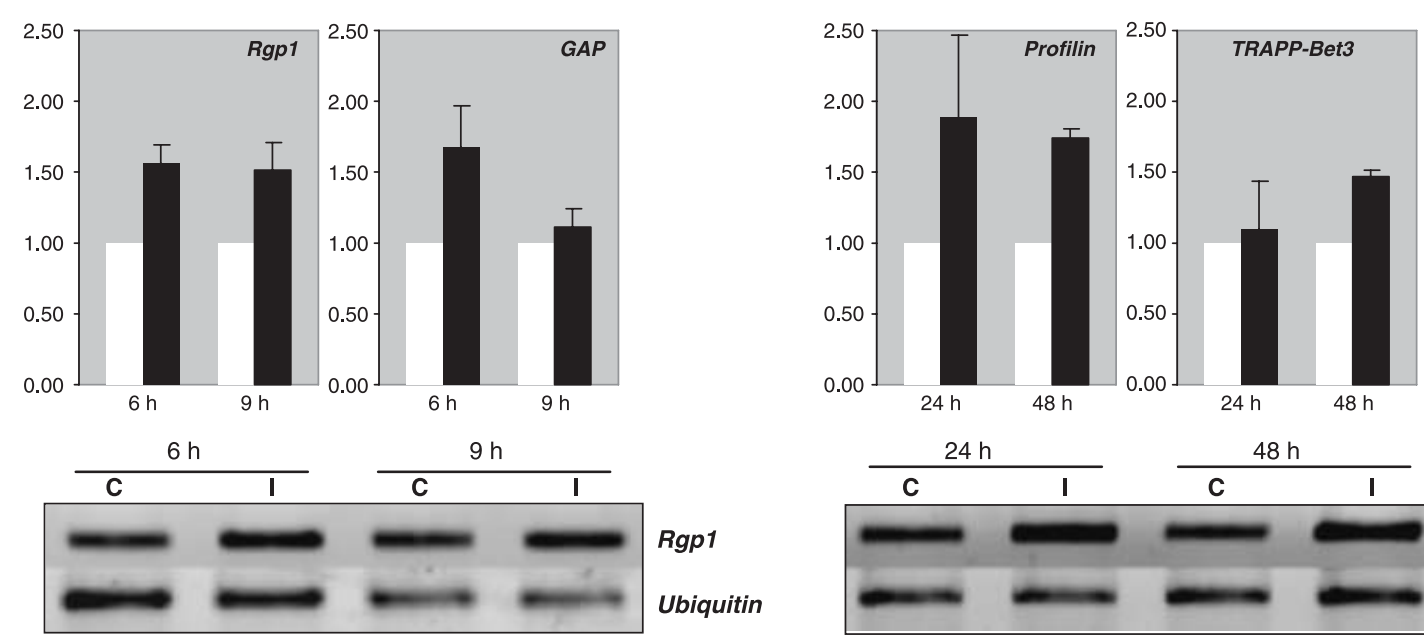

Rgp1

Ubiquitin

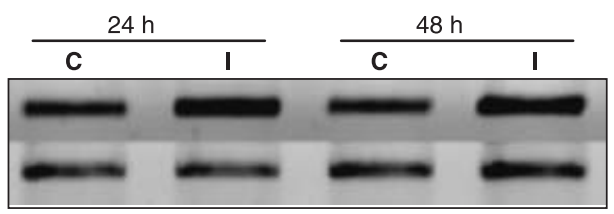

Profilin

Ubiquitin
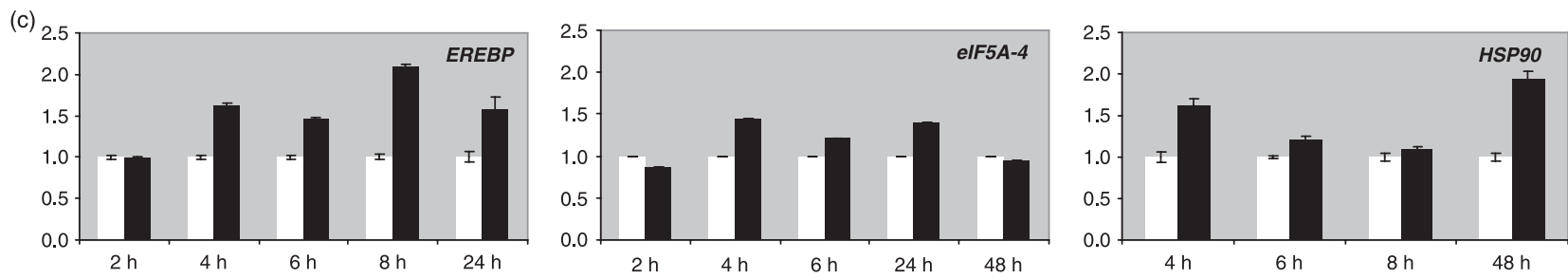

Figure 2 Validation of macroarray data. Expression patterns of genes selected by macroarray analysis during Magnaporthe oryzae infection. (a) Northern blot analysis with the indicated gene probes was performed on RNA samples obtained from rice leaves at different times after inoculation with fungal spores. Ten micrograms of total RNA from non-infected and infected rice leaves at the indicated times after inoculation were used in Northern blot analysis (C, control non-infected; I, M. oryzae-infected). RNA loading of each sample was verified by hybridization with the CDNA for the 185 ribosomal RNA. (b) Reverse transcriptase-polymerase chain reaction (RT-PCR) analysis of $M$. oryzae-infected (black bars) and non-infected (white bars) rice leaves. Top panels show the changes in transcript abundance of the indicated genes relative to the ubiquitin gene (loading control). The data shown are the mean values \pm standard deviation of three independent experiments (error bars are indicated). Representative RT-PCR analyses for the Rgp1 and profilin genes are presented in the bottom panels. (c) Changes in transcript abundance in rice leaves as determined by real-time quantitative RT-PCR (qRT-PCR) analysis. The relative expression of the EREBP, elF5A-4 and HSP9O genes in fungal-infected (black bars) and non-infected (white bars) rice leaves is shown. To normalize the qRT-PCR data, each gene was compared with the actin transcript. Two biological replicates were used for these expression studies. See tables for gene abbreviations.

between transgenic and wild-type plants also revealed the over-expression of genes playing a role in protein synthesis, folding and stabilization (20.1\% of the total number of ESTs) in cecropin A plants, particularly genes involved in the folding and stabilization of proteins that enter into the secretory pathway: calnexin (two distinct genes), calreticulin, HSP90 and HSP22, DNAJ heat shock protein (two distinct genes) and PDI. The expression of a random set of selected genes that were identified as being over-expressed in cecropin A plants in macroarray experiments was confirmed by Northern blot 


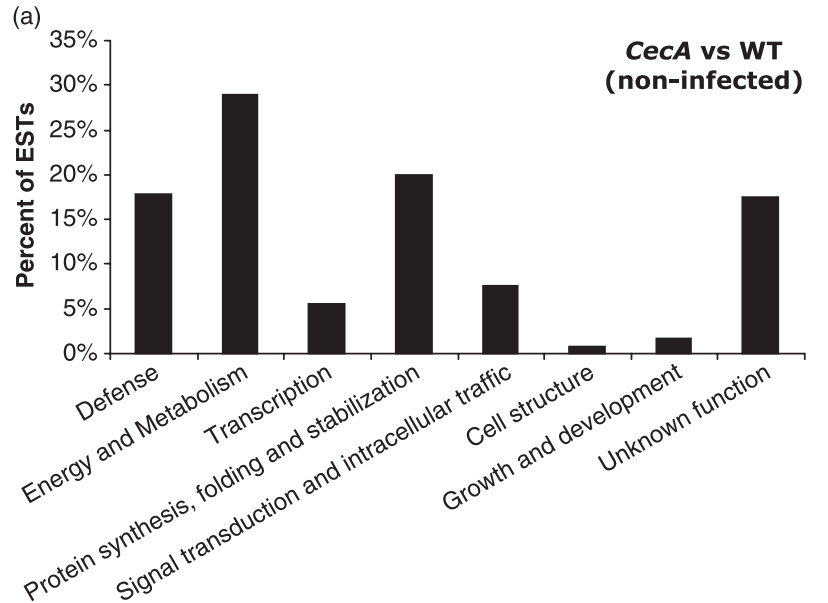

(b)

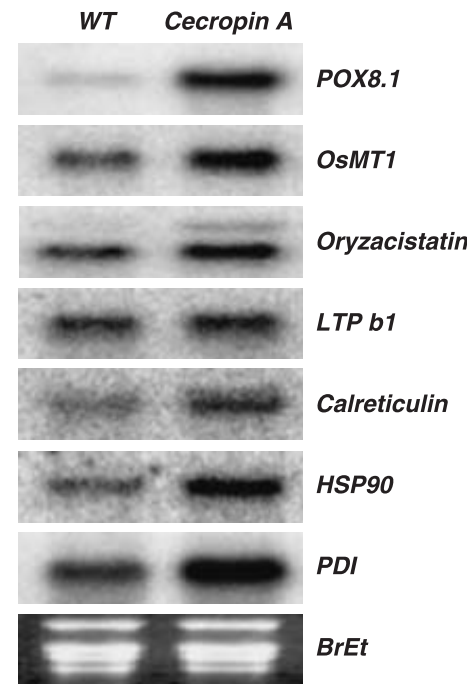

Figure 3 Gene expression data using the rice macroarray of cecropin A plants. (a) Distribution of expressed sequence tags (ESTs) with altered expression in cecropin $A$ plants compared with wild-type plants amongst the different functional categories. CecA, cecropin A; WT, wild-type. (b) Northern blot analysis of genes showing differential expression in cecropin A plants compared with wild-type plants grown under normal growth conditions. See tables for gene abbreviations.

(Figure 3b). Overall, the results of RNA gel blot were consistent with the expression data obtained by macroarray analysis.

The transgenic cecropin $A$ plants under study were produced by Agrobacterium-mediated transformation using the hygromycin resistance gene (hptll, hygromycin phosphotransferase) as the selectable marker. Therefore, there was the possibility that the expression of the selectable marker gene might influence the expression of rice genes. Accordingly, gene expression studies were performed with transgenic rice transformed with the empty vector (the pCAMBIA 1300 plasmid containing the hptll gene). None of the rice genes that were over-expressed in cecropin A plants showed differential expression in rice plants expressing the empty vector compared with wild-type plants (results not shown), indicating that the expression of the hygromycin resistance gene had little effect, if any, on the gene expression in rice. In other studies, the expression of the commonly used marker gene nptll (neomycin phosphotransferase), conferring kanamycin resistance, has not been reported to induce changes in the Arabidopsis transcriptome (El Ouakfaoui and Miki, 2005).

In summary, the comparative analysis of gene expression between transgenic and wild-type rice plants grown under optimal conditions revealed changes in the expression of an important number of rice genes. In particular, genes involved in protection against oxidative stress and genes related to processes of synthesis, folding and stabilization of proteins that enter into the secretory pathway were found to be over-expressed in cecropin $A$ rice. Together, these findings indicate that the transgenic expression of cecropin $A$ in rice has an impact on host gene expression.

\section{Cecropin $A$ accumulates in the ER in transgenic rice plants}

Because an important number of rice genes that play a role in the processes of protein folding and stabilization in the ER are over-expressed in cecropin $A$ plants, and because the cecropin A gene introduced into rice plants was engineered to retain cecropin $A$ in the ER, this subcellular compartment was investigated for the accumulation of cecropin A. To this end, subcellular fractionation experiments were performed on both wild-type and transgenic rice plants, followed by Western blot analysis using a polyclonal antibody raised against cecropin A (Coca et al., 2006). After homogenization of rice leaves from wild-type and transgenic plants, the organelles were separated on a discontinuous sucrose gradient (20\%-70\% sucrose). Fractions were collected and separated by sodium dodecylsulphate-polyacrylamide gel electrophoresis (SDS-PAGE), followed by Western blotting. Membranes were probed with anti-cecropin A or with antiserum raised against the BiP protein, an ER marker (luminal binding protein). Cecropin A was detected in the ER fraction (30\%-50\% sucrose) and co-fractionated with the BiP protein in transgenic plants, indicating that cecropin A and BiP share the same organellar compartment: the ER (Figure 4).

\section{Enhanced tolerance to oxidative stress induced by hydrogen peroxide $\left(\mathrm{H}_{2} \mathrm{O}_{2}\right)$ in cecropin $A$ rice plants}

The observation that genes encoding ROS-scavenging enzymes and, in particular, peroxidases (three distinct peroxidase rice 
Table 2 Rice genes that are over-expressed by 2.5 fold or more in cecropin A plants compared with wild-type plants, classified according to functional category

Description* ${ }^{*}$ Accession numbert $\quad$ Number of ESTsł Expression ratio§

\section{Disease/defence}

Acidic endochitinase

Band 7 family protein, strong similarity to hypersensitive-induced response protein

AK065866

Carbonic anhydrase 3

AK111965

AF182806

Glutathione-S-transferase (GSTU6)

AK108376

Glycine-rich protein (GRP 0.9)

IAI2 mRNA for wound-induced protein homologue

$\times 54449$

\section{Energy and metabolism}

Adenosine kinase

BN000551

\section{$\Delta$-12 oleate desaturase-like}

3-Deoxy-D-arabino heptulosonate-7-phosphate synthase (DAHPS2 gene)

AK100710

AK069358

AK065239

AB122058

Farnesyl-pyrophosphate synthetase fps2

Ferredoxin-dependent glutamate synthase

Flavin-containing monooxygenase family protein

XM_474182

Y12595

Fructose-bisphosphate aldolase, precursor

AK071801

AK073758

Glyceraldehyde-3-phosphate dehydrogenase

AK103777

3-Ketoacyl-CoA thiolase-like protein

Lactoylglutathione lyase family protein

Lysyl-tRNA synthetase

5-Methyltetrahydropteroyltriglutamate-homocysteine S-methyltransferase

Magnesium-chelatase subunit H (Mg-protoporphyrin IX chelatase subunit H)

Magnesium-protoporphyrin IX monomethyl ester (oxidative) cyclase

Malate dehydrogenase (MDH)

Mevalonate kinase

NADP-dependent malic enzyme

NADP-dependent malic enzyme

NADP-dependent malic enzyme (NADP-ME2)

AK061948

AK1 19669

AK099302

AK099069

AK069545

AK069333

AF444195

AP008207

AK121770

D16499 
Table 2 (Continued)

\begin{tabular}{|c|c|c|c|}
\hline Description* & Accession numbert & Number of ESTs $\ddagger$ & Expression ratio§ \\
\hline Photosystem I reaction centre subunit IV & AP008213 & 1 & 4.1 \\
\hline Photosystem II 10-kDa polypeptide & AK121083 & 1 & 2.7 \\
\hline Phytoene synthase (psy gene) & AK070716 & 1 & 3.3 \\
\hline 23-kDa polypeptide of photosystem II & AF052203 & 2 & 2.9 \\
\hline Pyridoxal kinase & AK066514 & 1 & 5.4 \\
\hline Ribulose-1,5-bisphosphate carboxylase/oxygenase small subunit & AK070257 & 1 & 4.7 \\
\hline Ribulose-1,5-bisphosphate carboxylase/oxygenase small subunit & AY445627 & 1 & 2.7 \\
\hline Ribulose-5-phosphate-3-epimerase & AF047444 & 1 & 4.4 \\
\hline RINO1 mRNA for myo-inositol phosphate synthase & AB012107 & 1 & 2.7 \\
\hline S-Adenosyl methionine synthetase (pRSAM-1) & Z26867 & 1 & 2.9 \\
\hline Sedoheptulose-1,7-bisphosphatase precursor & AY188797 & 1 & 3.8 \\
\hline Succinyl-CoA ligase (GDP-forming) $\beta$-chain, mitochondrial & AK103525 & 1 & 2.6 \\
\hline Tetraacyldisaccharide 4'-kinase (lipid A 4'-kinase) & AK070220 & 1 & 4.7 \\
\hline Transketolase-like protein & AK066830 & 2 & 3.8 \\
\hline Triosephosphate isomerase & AK069488 & 2 & 2.9 \\
\hline Type I light-harvesting chlorophyll a/b-binding protein of photosystem II (LHCPII) & D00641 & 6 & 2.9 \\
\hline Ubiquinol-cytochrome c reductase complex $8.0 \mathrm{kDa}$ & AK062745 & 1 & 3.9 \\
\hline$\zeta$-Carotene desaturase precursor (zds) & AF054629 & 1 & 2.6 \\
\hline \multicolumn{4}{|l|}{ 3. Transcription } \\
\hline Basic helix-loop-helix (bHLH) family protein & AK073385 & 2 & 2.8 \\
\hline Basic helix-loop-helix (bHLH) family protein & AP008207 & 1 & 2.9 \\
\hline Basic helix-loop-helix (bHLH) family protein & AP003683 & 1 & 7.5 \\
\hline DNA-binding protein & AP008213 & 1 & 2.8 \\
\hline Ethylene-responsive element binding protein, EREBP-type transcription factor & AF364176 & 1 & 11.1 \\
\hline High mobility group protein (HMG1) & AF541859 & 1 & 3.9 \\
\hline Leucine zipper-containing protein & AK101630 & 1 & 2.5 \\
\hline Myb family transcription factor & AK103973 & 1 & 3.8 \\
\hline RNA helicase & AK101403 & 1 & 3.4 \\
\hline RNA helicase $R H 25$ & AK067570 & 1 & 6.0 \\
\hline Transcriptional regulators of NagCIXyIR (ROK)-like & AK101816 & 1 & 2.9 \\
\hline Zinc finger (C3HC4-type RING finger) family protein & AK067585 & 1 & 3.1 \\
\hline \multicolumn{4}{|l|}{ 4. Protein synthesis, folding and stabilization } \\
\hline$\beta 5$ subunit of 205 proteasome (OSPBE1) & AB026568 & 1 & 4.9 \\
\hline Calnexin & AK069118 & 2 & 2.9 \\
\hline Calnexin & AK061185 & 1 & 2.8 \\
\hline Calreticulin-3 precursor & AK060834 & 1 & 3.7 \\
\hline Cytoplasmic ribosomal protein 513 (xd3 gene) & AJ417519 & 1 & 3.6 \\
\hline DNAJ heat shock N-terminal domain-containing protein & AK070019 & 1 & 3.6 \\
\hline $\begin{array}{l}\text { DNAJ heat shock family protein similar to DnaJ homologue subfamily B member } \\
11 \text { precursor }\end{array}$ & AK062718 & 1 & 3.5 \\
\hline Eukaryotic translation initiation factor $5 \mathrm{~A}$ (elF5A) & AJ312906 & 1 & 2.5 \\
\hline Eukaryotic translation initiation factor 6 (elF6) & AK074012 & 1 & 7.2 \\
\hline Heat shock protein 90 (HSP9O) & AB037681 & 4 & 2.6 \\
\hline Heat shock protein precursor (HSP22), low molecular weight & AK105464 & 1 & 7.0 \\
\hline Mitochondrial 285 ribosomal protein S29-related & AK065624 & 1 & 3.4 \\
\hline Plastid-specific 30 S ribosomal protein 1, chloroplast precursor & AK104733 & 1 & 8.0 \\
\hline Protein disulphide isomerase (PDI) & AY987391 & 2 & 4.6 \\
\hline 265 protease regulatory subunit 4 homologue (TAT-binding protein homologue 2) & D17789 & 1 & 2.7 \\
\hline $40 S$ ribosomal protein $\$ 2$ & AK064984 & 1 & 3.5 \\
\hline 405 ribosomal protein 58 & AK068316 & 2 & 3.0 \\
\hline $40 S$ ribosomal protein 59 & AK104660 & 1 & 3.3 \\
\hline 405 ribosomal protein 511 & AK120520 & 1 & 7.2 \\
\hline 405 ribosomal protein 514 & AK121223 & 1 & 3.0 \\
\hline $40 \mathrm{~S}$ ribosomal protein $515 a$ & AK240912 & 1 & 2.6 \\
\hline
\end{tabular}


Table 2 (Continued)

\begin{tabular}{|c|c|c|c|}
\hline Description* & Accession numbert & Number of ESTsł & Expression ratio§ \\
\hline 405 ribosomal protein S21 & AP008209 & 1 & 2.6 \\
\hline $40 S$ ribosomal protein $\$ 21$ & D12633 & 1 & 2.5 \\
\hline 405 ribosomal protein 523 & AK241653 & 1 & 2.9 \\
\hline 40 S ribosomal protein S24 & AK058248 & 1 & 7.4 \\
\hline $40 S$ ribosomal protein 528 & AK242697 & 1 & 5.1 \\
\hline $40 S$ subunit ribosomal protein & D12633 & 1 & 3.7 \\
\hline 60S ribosomal protein $L 17$ & AK120324 & 2 & 3.4 \\
\hline $60 S$ ribosomal protein $\angle 37 a$ & AK119801 & 1 & 3.9 \\
\hline $60 S$ ribosomal protein L38 & AK058262 & 1 & 3.1 \\
\hline Ribosomal protein $\angle 13 a$ & AK103048 & 1 & 4.0 \\
\hline Signal peptidase $1-1$ & AK069581 & 2 & 4.6 \\
\hline Translation elongation factor $1 \alpha(E F-1 \alpha)$ & D63581 & 2 & 3.0 \\
\hline Ubiquitin-conjugating enzyme E2-17 kDa & AK060954 & 1 & 5.5 \\
\hline Ubiquitin/ribosomal protein S27a & AK061988 & 2 & 2.6 \\
\hline Ubiquitin-like protein & AK058725 & 1 & 3.3 \\
\hline YK704 mRNA for acidic ribosomal protein PO & D21130 & 1 & 5.9 \\
\hline \multicolumn{4}{|l|}{ 5. Signal transduction and Intracellular traffic } \\
\hline BRI1-kDa interacting protein 102 (Bip 102) & AB117990 & 1 & 11.6 \\
\hline BRI1-kDa interacting protein 103 (proton pump interacting protein) & AB117987 & 1 & 3.1 \\
\hline Calmodulin & AK069620 & 1 & 5.1 \\
\hline Calmodulin-binding protein & AK072545 & 1 & 2.9 \\
\hline \multicolumn{4}{|l|}{ Rapid alkalinization factor (RALF) family protein similar } \\
\hline Receptor-like protein kinase (DUF26-like protein) & AY847141 & 4 & 7.5 \\
\hline Profilin & AK121519 & 1 & 3.4 \\
\hline Protein kinase family protein & AK120660 & 1 & 2.6 \\
\hline Purine permease (putative) & AK072660 & 1 & 3.1 \\
\hline SEC14 cytosolic factor & AK064540 & 3 & 3.4 \\
\hline Stomatal cytokinesis-defective 1 (SCD1) & NM_193619 & 1 & 3.5 \\
\hline Sulphonylurea receptor-like protein & AK121451 & 1 & 3.3 \\
\hline Transport protein, similar to transport protein Sec23A & AK067849 & 1 & 2.9 \\
\hline \multicolumn{4}{|l|}{ 6. Cell structure } \\
\hline Actin-related protein 4 & AK101582 & 1 & 10.8 \\
\hline Chloroplast inner envelope protein & AK120578 & 1 & 9.4 \\
\hline \multicolumn{4}{|l|}{ 7. Growth and division } \\
\hline Dormancy/auxin-associated family protein & AK064815 & 1 & 3.5 \\
\hline Dormancy-associated protein & AF467730 & 1 & 4.0 \\
\hline EL2 gene & D64038 & 1 & 2.8 \\
\hline Light-induced protein, CR9 & X68807 & 1 & 8.7 \\
\hline \multicolumn{4}{|l|}{ 8. Unclassified or unknown function } \\
\hline 21-kDa polypeptide; translationally controlled tumour protein homologue (TCTP) & AK105453 & 1 & 2.6 \\
\hline 33-kDa secretory protein & AK061425 & 2 & 2.8 \\
\hline 33-kDa secretory protein & AK240901 & 1 & 6.8 \\
\hline Agenet domain-containing protein & AK072110 & 1 & 3.5 \\
\hline Centromeric protein-related & AP008208 & 1 & 2.9 \\
\hline Crp1 protein & AK070212 & 1 & 4.0 \\
\hline Expressed protein & AK101256 & 1 & 13.8 \\
\hline Expressed protein & AK098951 & 1 & 3.4 \\
\hline Expressed protein & AK068661 & 3 & 2.6 \\
\hline Expressed protein & AK069538 & 1 & 2.6 \\
\hline Expressed protein & AK068925 & 1 & 2.7 \\
\hline Genomic sequence & AP008209 & 4 & 2.7 \\
\hline Genomic sequence & AP008210 & 1 & 2.6 \\
\hline Genomic sequence & AP008211 & 1 & 9.0 \\
\hline
\end{tabular}


Table 2 (Continued)

\begin{tabular}{|c|c|c|c|}
\hline Description* & Accession numbert & Number of ESTs $\ddagger$ & Expression ratio§ \\
\hline Genomic sequence & AP008213 & 1 & 4.3 \\
\hline Genomic sequence & AP008214 & 1 & 3.0 \\
\hline Genomic sequence & AP008217 & 1 & 2.7 \\
\hline Hypothetical protein & AK240639 & 2 & 4.2 \\
\hline Hypothetical protein & AB110171 & 4 & 3.3 \\
\hline Hypothetical protein & AK073234 & 1 & 2.9 \\
\hline Hypothetical protein, expressed under carbonate stress & AB053296 & 1 & 2.5 \\
\hline Leucine-rich repeat protein & AK069710 & 1 & 4.6 \\
\hline LTR retrotransposon & AK242671 & 1 & 3.2 \\
\hline Protein gypsy/Ty3 element polyprotein & AK119906 & 1 & 3.7 \\
\hline Unknown protein & XM_463125 & 1 & 7.3 \\
\hline Unknown protein & AK068219 & 1 & 5.6 \\
\hline Unknown protein & AK099155 & 1 & 3.2 \\
\hline Unknown protein & AK071570 & 1 & 2.7 \\
\hline Unknown protein & AK240888 & 1 & 2.7 \\
\hline Unknown protein & AK243523 & 1 & 2.6 \\
\hline Unknown protein & AK059554 & 1 & 3.6 \\
\hline
\end{tabular}

*Unigenes for which the transcript level was up-regulated are listed by functional category according to the Munich Information Centre for Protein Sequences (MIPS, http://mips.gsf.de). Only genes showing a ratio of $\geq 2.5$ (cecropin A vs. wild-type) are listed.

†Accession numbers for unigenes (GENBANK and KOME databases).

¥Number of expressed sequence tag (EST) components in each gene is indicated.

$\S$ Expression ratio: signal intensity ratio of leaves from cecropin A plants over leaves of wild-type plants

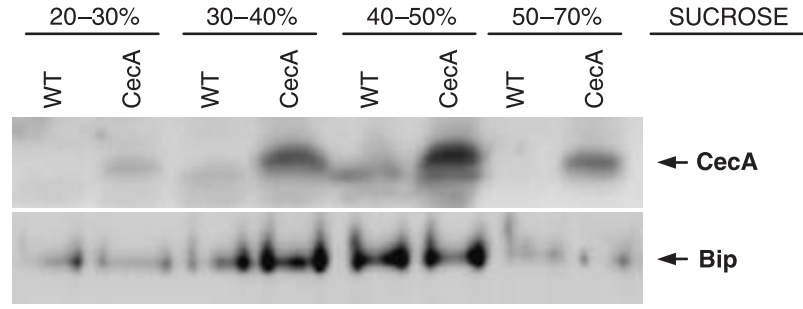

Figure 4 Co-fractionation of cecropin A and BiP proteins in transgenic rice plants. Total homogenates from wild-type (WT) and cecropin $A$ (CecA) plants were subjected to centrifugation on a discontinuous sucrose gradient $(20 \%-30 \%, 30 \%-40 \%, 40 \%-50 \%$ and $50 \%-70 \%$ sucrose). Each fraction was subjected to immunoblot analysis with anti-cecropin A (top panel) or anti-BiP (bottom panel). genes) are expressed at very high levels in cecropin $A$ plants compared with wild-type plants, in the absence of the pathogen, prompted us to investigate the response of transgenic plants to treatment with the ROS-generating agent $\mathrm{H}_{2} \mathrm{O}_{2}$, which is a substrate for a wide range of plant peroxidases. In this respect, external application of $\mathrm{H}_{2} \mathrm{O}_{2}$ has long been used to elicit oxidative stress in plants. Leaves of cecropin $A$ and wild-type plants were treated with $\mathrm{H}_{2} \mathrm{O}_{2}$ and then stained with nitroblue tetrazolium (NBT). As shown in Figure 5 (top panels), intense staining was observed in areas randomly distributed on the leaves of wild-type plants, indicating that superoxide radicals $\left(\mathrm{O}_{2}^{-}\right)$accumulate in these
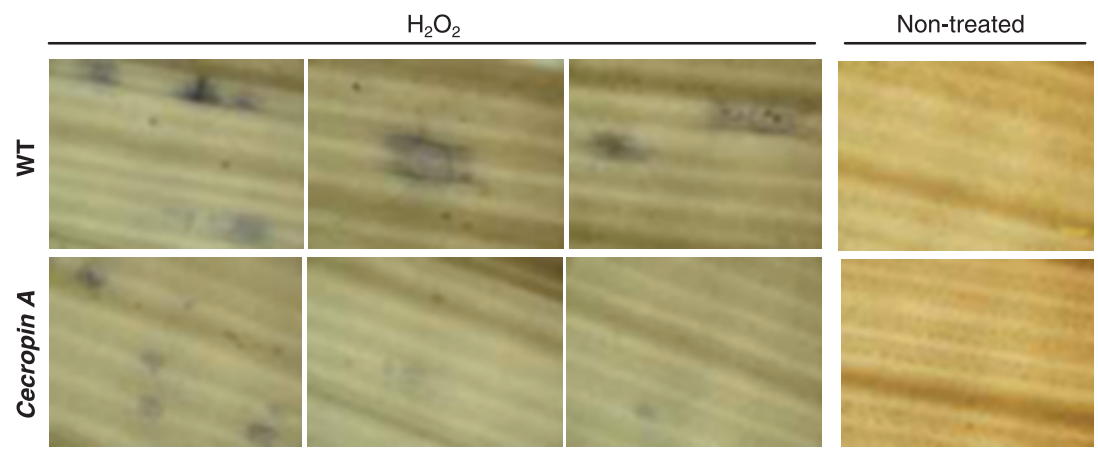

Figure 5 Effect of treatment with $\mathrm{H}_{2} \mathrm{O}_{2}$ in leaves of cecropin $A$ (a) and wild-type (WT) (b) plants. Leaves of cecropin $A$ and wild-type plants were treated with $\mathrm{H}_{2} \mathrm{O}_{2}$ for $8 \mathrm{~h}$ and then stained with nitroblue tetrazolium (NBT). After bleaching, leaves were examined by light microscopy. The reduction of NBT to formazan yields a bluish precipitate in the presence of superoxide radicals $\left(\mathrm{O}_{2}^{-}\right)$. 


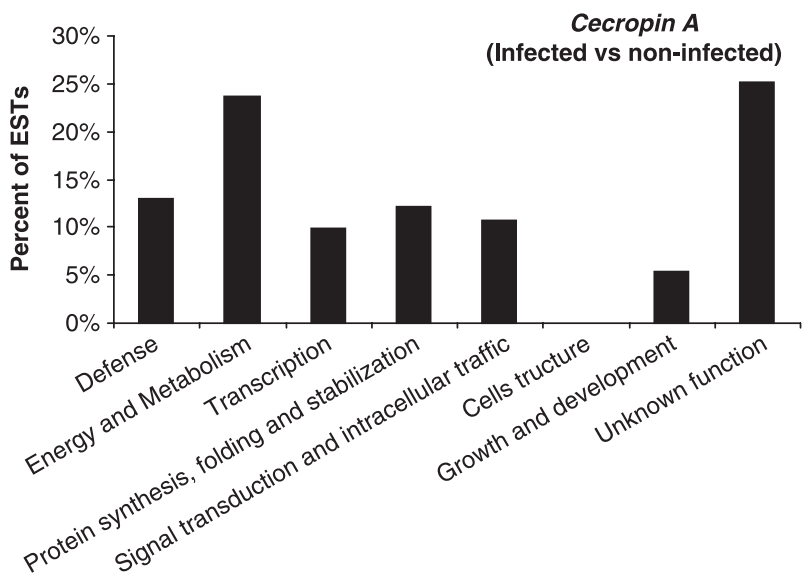

Figure 6 Functional classification of expressed sequence tags (ESTs) showing responsiveness to infection by the blast fungus Magnaporthe oryzae in cecropin A rice plants.

leaves after $\mathrm{H}_{2} \mathrm{O}_{2}$ treatment. In contrast, accumulation of $\mathrm{O}_{2}^{-}$ was barely detected in the leaves of cecropin $A$ plants (Figure 5, bottom panels), confirming that transgenic plants are more tolerant than wild-type plants to the oxidative stress imposed by $\mathrm{H}_{2} \mathrm{O}_{2}$ treatment. This finding is in agreement with the results from macroarray analysis, which indicated that antioxidant systems are activated in transgenic plants in the absence of pathogen challenge.

\section{Analysis of inducible rice defence responses in cecropin $A$ rice under infection conditions}

It was determined whether transgenic expression of the cecropin A gene has an influence on the defence mechanisms that are usually activated in rice plants on challenge with the blast fungus. To this end, the rice macroarray was used to compare gene expression profiles in non-infected and M. oryzae-infected cecropin A plants. Genes whose expression was up-regulated in transgenic plants during the early stage of infection, namely at $6 \mathrm{~h}$ pi, were identified. Changes in gene expression that might occur in cecropin $A$ plants at later stages of the infection process were not investigated in this work.

Our study revealed that 94 unique genes were up-regulated in transgenic rice plants in response to $M$. oryzae infection, showing a difference equal to or greater than twofold. A description of the fungal-induced genes in cecropin A plants and their distribution in functional categories is shown in Table 3 and Figure 6, respectively. This study revealed that many of the genes that were up-regulated in response to $M$. oryzae infection in wild-type plants were also up-regulated in cecropin $A$ plants in response to fungal infection (see
Tables 1 and 3). The genes that were up-regulated in $M$. oryzae-infected cecropin $A$ lines included those encoding lipid transfer protein (two genes), cysteine proteinase inhibitor, glycine-rich protein, ascorbate peroxidase, PDI, mitogenactivated protein kinase (MAPK), bHLH family protein, remorin and vacuolar proton-translocating ATPase (subunit E).

\section{Discussion}

In this work, the construction of a subtracted cDNA library containing rice genes that are induced during the early stage of the rice-blast interaction (3-48 h after inoculation) is reported. One hundred and sixty-two unique rice genes were identified as being up-regulated in response to infection by the rice blast fungus. Of these, 143 genes were found to be transcriptionally activated at 3 and $6 \mathrm{~h}$ after inoculation. From the different functional categories in which the $M$. oryzae-induced rice genes were placed, it appears that many different kinds of gene are involved in the early response of rice to the blast fungus. Clearly, the complexity of the plant response to pathogen infection indicates that the expression of plant genes belonging to different functional categories is reprogrammed. In this study, 331 of the 590 ESTs showing differential expression at one or more of the three time points studied (3, 6 and $48 \mathrm{~h}$ after inoculation) were characterized. This number represents a small fraction of the total number of ESTs contained in the subtracted cDNA library. It should be mentioned that the experimental design for preparation of the cDNA library comprised sampling of leaf tissues at five time points after inoculation $(3,6,9,24$ and $48 \mathrm{~h}$ ), and that, in this work, differential screening of the macroarray was carried out with RNA samples obtained at 3 , 6 and $48 \mathrm{~h}$ after inoculation only. In addition, subtractive products may contain cDNAs that are induced at more than one time point after inoculation, which may also account for the large proportion of ESTs contained in the library. Although a large number of ESTs remain to be characterized, the results presented here provide a measure of the diversity of genes in the cDNA collection which show responsiveness to $M$. oryzae infection in rice plants.

\section{Rice genes expressed during the early stages of infection with the rice blast fungus}

Differential hybridization of the macroarray revealed the induction of expression of genes playing an important role in disease resistance, such as $P R$ genes (van Loon et al., 2006) and genes involved in tolerance to oxidative stress and the detoxification of ROS. The production of ROS, including $\mathrm{H}_{2} \mathrm{O}_{2}$ 
Table 3 Genes up-regulated by Magnaporthe oryzae infection in cecropin A plants, sorted according to functional category

\begin{tabular}{|c|c|c|c|}
\hline Description* & Accession numbert & Number of ESTs $\neq$ & Expression ratio§ \\
\hline \multicolumn{4}{|l|}{ 1. Disease/defence } \\
\hline Ascorbate peroxidase, thylakoid-bound & AB114856 & 2 & 2.6 \\
\hline Carbonic anhydrase 3 & AF182806 & 1 & 2.0 \\
\hline Cysteine proteinase inhibitor & AK119511 & 1 & 3.4 \\
\hline Defender against apoptotic death 1 protein (DAD1) & D89727 & 1 & 2.1 \\
\hline Glycolate oxidase & AF022740 & 1 & 2.2 \\
\hline Glyoxalase I & АВ017042 & 2 & 2.3 \\
\hline Glycine-rich protein (GRP 0.9) & X54449 & 1 & 3.0 \\
\hline Lipid transfer protein (LPT IV) & AK070414 & 1 & 3.0 \\
\hline Lipid transfer protein, b1 & X83434 & 1 & 2.0 \\
\hline Oryzacystatin & S49967 & 4 & 2.2 \\
\hline Protein, similar to CMV 1a interacting protein $1 /$ tobacco & AK059127 & 1 & 2.2 \\
\hline Superoxide dismutase $(\mathrm{Fe})$ & AK111656 & 1 & 2.1 \\
\hline \multicolumn{4}{|l|}{ 2. Energy and metabolism } \\
\hline 23-kDa polypeptide of photosystem II & AF052203 & 3 & 2.0 \\
\hline 33-kDa oxygen-evolving protein of photosystem II & AK119515 & 1 & 3.2 \\
\hline Adenylosuccinate synthetase & AK120407 & 1 & 3.4 \\
\hline Alanine aminotransferase & AK067732 & 1 & 2.0 \\
\hline Aspartate kinase-homoserine dehydrogenase & AK073790 & 1 & 2.6 \\
\hline ATP-NAD kinase family protein & AK073719 & 1 & 2.0 \\
\hline Chlorophyll a/b-binding protein (RCABP69) & AF058796 & 3 & 2.1 \\
\hline Chlorophyll a/b-binding protein precursor (Cab26) & AF094776 & 1 & 2.0 \\
\hline Dehydrogenase & AP008216 & 1 & 2.0 \\
\hline Ferredoxin-dependent glutamate synthase & Y12595 & 1 & 2.7 \\
\hline Hydrolase, $\alpha / \beta$ fold family protein & AK070827 & 1 & 2.0 \\
\hline $\begin{array}{l}\text { Magnesium-protoporphyrin IX monomethyl ester (oxidative) } \\
\text { cyclase, chloroplast precursor }\end{array}$ & AK069333 & 1 & 3.3 \\
\hline Non-cyanogenic $\beta$-glucosidase precursor & AK100820 & 1 & 2.1 \\
\hline Oxygen-evolving enhancer protein 3, chloroplast & AK099127 & 1 & 2.1 \\
\hline Oxygen-evolving protein & D21109 & 1 & 2.0 \\
\hline Phosphoenolpyruvate carboxykinase & AK102392 & 1 & 2.0 \\
\hline Phosphoribulokinase precursor & AF529237 & 1 & 2.8 \\
\hline Photosystem I reaction centre subunit VI, chloroplast & AP008213 & 1 & 4.0 \\
\hline Photosystem I reaction centre subunit VI, chloroplast & AF093635 & 1 & 2.0 \\
\hline Photosystem I reaction centre subunit PSI-N, chloroplast & AK059037 & 1 & 2.2 \\
\hline Photosystem I antenna protein & AK105002 & 1 & 2.2 \\
\hline Ribulose-bisphosphate carboxylase small chain C, chloroplast precursor & AY445627 & 4 & 2.9 \\
\hline Threonyl-tRNA synthetase & AK058738 & 1 & 4.1 \\
\hline UGP mRNA for UDP-glucose pyrophosphorylase & AB062606 & 1 & 5.4 \\
\hline \multicolumn{4}{|l|}{ 3. Transcription } \\
\hline 29-kDa ribonucleoprotein A, chloroplast precursor & AK061072 & 1 & 4.1 \\
\hline Basic helix-loop-helix (bHLH) family protein & AK073385 & 3 & 2.6 \\
\hline Basic helix-loop-helix (bHLH) family protein & AP008207 & 2 & 2.9 \\
\hline DNA-binding protein & AP008213 & 1 & 2.7 \\
\hline HMG1 protein (HMG1) & AF541859 & 1 & 2.4 \\
\hline Nuclear RNA-binding protein (RGGA) & AK121001 & 1 & 2.3 \\
\hline Ethylene-responsive element binding protein, EREBP-type transcription factor & AF364176 & 2 & 2.0 \\
\hline RNA-binding protein homologue & AK060161 & 1 & 2.0 \\
\hline YT521-B-like family protein & AK119641 & 1 & 2.0 \\
\hline \multicolumn{4}{|l|}{ 4. Protein synthesis, folding and stabilization } \\
\hline Plastid-specific 305 ribosomal protein 1, chloroplast precursor & AK104733 & 3 & 2.5 \\
\hline Protein disulphide isomerase (PDI) & AY224470 & 1 & 2.0 \\
\hline Protein disulphide isomerase (PDI) & AY987391 & 1 & 2.7 \\
\hline $40 S$ ribosomal protein $\$ 21$ & D12633 & 1 & 2.0 \\
\hline
\end{tabular}


Table 3 (Continued)

\begin{tabular}{|c|c|c|c|}
\hline Description* & Accession numbert & Number of ESTs $\neq$ & Expression ratio§ \\
\hline 40 S ribosomal protein $\$ 25$ & AK099010 & 2 & 3.7 \\
\hline $60 S$ ribosomal protein $\angle 37 a$ & AK119801 & 1 & 2.1 \\
\hline Ribosomal protein L17 & AK120273 & 1 & 2.7 \\
\hline Ribosomal protein S8 & AK241816 & 1 & 2.2 \\
\hline Translation initiation factor (GOS2) & AF094774 & 2 & 2.0 \\
\hline Ubiquitin-conjugating enzyme & AK120251 & 1 & 2.0 \\
\hline Ubiquitin-like protein & AK058725 & 2 & 3.2 \\
\hline \multicolumn{4}{|l|}{ 5. Signal transduction and intracellular traffic } \\
\hline Aquaporin PIP2.8 & AK109439 & 1 & 2.2 \\
\hline BRI1-kDa interacting protein, Bip 128 & AK066179 & 1 & 4.7 \\
\hline Mitogen-activated protein kinase (MAPK) phosphatase & AK067768 & 1 & 2.7 \\
\hline Mitogen-activated protein kinase homologue & AK111579 & 1 & 3.3 \\
\hline Mitogen-activated protein kinase, wjumk1 & AJ512643 & 1 & 2.1 \\
\hline Non-phototrophic hypocotyl 1a & AK066816 & 2 & 3.7 \\
\hline Phosphate transporter & AK065252 & 1 & 2.3 \\
\hline Receptor for activated C-kinase (RWD) & D38231 & 1 & 2.2 \\
\hline Remorin 1 & AK106182 & 3 & 4.4 \\
\hline Transport protein particle (TRAPP) Bet3 component & AK111377 & 1 & 2.0 \\
\hline Vacuolar proton-translocating ATPase subunit E & AK071200 & 1 & 8.3 \\
\hline
\end{tabular}

\section{Cell structure}

\section{Growth and division}

Auxin-responsive protein, IAA16

Dormancy-associated protein

Light-induced protein

$\begin{array}{lll}\text { AK241477 } & 1 & 2.1 \\ \text { AF467730 } & 3 & 2.2 \\ X 68807 & 3 & 2.4\end{array}$

8. Unclassified or unknown function

33-kDa secretory protein

Expressed protein

Expressed protein

Expressed protein

Expressed protein

Expressed protein

Expressed protein

Expressed protein

Expressed protein

Expressed protein

Genomic sequence

Hypothetical protein

Maternal G10-like protein

Pentatricopeptide repeat-containing protein

Reticulon family protein (RTNLB2)

TMS membrane protein/tumour differentially expressed protein (TDE)

X68807

*Unigenes for which the transcript level was up-regulated are listed by functional category according to the Munich Information Centre for Protein Sequences (MIPS, http://mips.gsf.de). Only genes showing a ratio of $\geq 2.0$ (infected vs. non-infected cecropin A plants) are listed. Those genes that are commonly induced in wild-type and cecropin $A$ plants in response to fungal infection are indicated in bold.

†Accession numbers for unigenes (GENBANK and KOME databases).

\#Number of expressed sequence tag (EST) components in each gene is indicated.

$\S$ Expression ratio: signal intensity ratio of infected leaves over non-infected leaves of cecropin A plants. 
and $\mathrm{O}_{2}{ }^{-}$, the so-called oxidative burst, is one of the earliest events in the plant defence response against pathogen attack (Lamb and Dixon, 1997). At low concentrations, ROS have beneficial effects on plant cells responding to pathogen attack by reinforcing plant cell walls and acting as signalling molecules for the mediation of responses to pathogen infection. They can also act directly to kill pathogens. However, high concentrations of ROS can result in noncontrolled oxidation of a variety of cellular components of the plant cell (DNA, proteins and membrane lipids), which may lead to cellular dysfunction, the appearance of necrotic lesions and, ultimately, to cell death. To control the steadystate level of ROS, plants possess a range of ROS-scavenging enzymes, namely peroxidases, catalases, ascorbate peroxidases, superoxide dismutases, peroxiredoxins, thioredoxins and glutathione peroxidases. Amongst the rice genes that were found to be up-regulated in response to $M$. oryzae infection were those encoding ascorbate peroxidase, catalase, peroxidase POX8.1, peroxiredoxin and thioredoxin. The expression of these genes was induced as early as 3-6 $\mathrm{h}$ after inoculation with fungal spores. The expression of a metallothionein gene (OSMT1), metallothioneins being essential for cellular processes of metal detoxification, was also induced in $M$. oryzae-infected rice.

The macroarray data also indicated that components of the machinery for protein synthesis, folding and modification were co-ordinately and rapidly up-regulated during infection of rice with the rice blast fungus $M$. oryzae. In particular, the induction of translation initiation factors (elF5A) and elongation factors (EF-1 $\alpha$ and EF-1 $\beta$ ) was observed. The up-regulation of genes encoding elF5A has also been described in the maize-Fusarium verticillioides pathosystem (Campo et al., 2004). It has been proposed that the different elF5As might facilitate the translation of subsets of mRNAs required for specific physiological functions, such as cell division or cell death. Further studies are required to elucidate whether the $M$. oryzae-induced elF5A rice gene facilitates translation of the set of mRNAs required for the rice defence response against fungal infection. With regard to the translation elongation factor EF-1, changes in the level of transcript accumulation have been reported to modulate the rate of apoptosis in mammalian cells (Duttaroy et al., 1998). In addition to their involvement in the detoxification of $\mathrm{H}_{2} \mathrm{O}_{2}$, thioredoxins and peroxiredoxins also participate in the thiol disulphide interconversion of proteins. Presumably, a coordinated up-regulation of components of the translational machinery will ensure the production of the newly requested defence proteins, these proteins being, in turn, part of the pre-invasive defence response of the rice plant.
An interesting observation arising from this study was that, in addition to inducing the expression of the genes involved in the translational machinery, fungal infection rapidly activated the expression of an important number of genes encoding components of the vesicle-associated transport machinery. The machinery for the transport of proteins between the organelles of the secretory pathway is highly conserved amongst eukaryotes and occurs by the budding of vesicles from a donor membrane and fusion with an acceptor membrane. Thus, the fusion of vesicles involves the interaction of $v$-SNAREs localized on the vesicle membrane and $t$ SNAREs localized on the target membrane (Jurgens, 2004). Additional proteins are also known to participate in the process of docking and fusion of transport vesicles to form protein complexes with v-SNAREs. Thus, v-SNARE interacts with a particular family of GTPases (Rab proteins) that participate in vesicle trafficking which, in turn, interact with GAP to hydrolyse GTP effectively. Of interest, $M$. oryzae infection rapidly induced the expression of components of the v-SNARE complex, namely the v-SNARE protein, Rgp1 and GAP. In Arabidopsis, pathogen-induced expression of a t-SNARE protein has been reported (Wick et al., 2003). Profilin, a protein that modulates actin polymerization and vesicular trafficking in plant cells (Aparicio-Fabre et al., 2006), and TRAPP (showing homology to yeast BET3), a protein involved in targeting and fusion of the ER to Golgi transport vesicles, were also up-regulated in the rice response to blast infection.

The macroarray data also revealed the fungal responsiveness of a rice gene encoding remorin. Remorin is a major component of plasma membrane lipid rafts (Mongrand et al., 2004). In Arabidopsis, the existence of lipid rafts, microdomains in the plasma membrane acting as 'signalling platforms' on which components of signal transduction cascades are locally condensed, is well documented (Bhat and Panstruga, 2005; Borner et al., 2005).

Taken together, a comparison of the gene expression profiles of $M$. oryzae-infected and non-infected Senia plants demonstrates that fungal infection results in the rapid activation of the protein secretory pathway and vesicle trafficking. All of these processes are co-ordinately up-regulated as part of the pre-invasive stage of the infection process. On perception of the pathogen, there is a massive request for defence proteins, and many of these proteins are targeted to the vacuole or the extracellular space. An increased level of components of the vesicular transport machinery will facilitate delivery of the defence-related proteins to the site of pathogen invasion. Increased vesicle fusion may also be required to repair the damage provoked by ROS to the 
plasma membrane in infected tissues. Accordingly, these differentially expressed genes or early response regulators prepare the cell for an efficient defence response. The determination of the mechanisms by which these genes mediate the secretion of specific vesicles will not only contribute to our understanding of the early signalling events occurring during rice-blast interaction, but should also provide unique insights into the regulation of protein secretion in plants.

\section{Transgenic expression of the cecropin A gene in rice has an impact on host gene expression}

In the literature, many reports have illustrated the usefulness of antimicrobial genes for plant protection against pathogens. The production of these antifungal proteins aims to interfere with the growth of target pathogens in infected plant tissues, as it is generally accepted that pathogen resistance is solely a result of the effect of the transgene product on the pathogen. The results presented here, however, demonstrate that the introduction of a fungus resistance trait in a rice cultivar induces alterations in the expression of specific endogenous genes under normal growth conditions, i.e. in the absence of the pathogen. Thus, genes encoding several ROS-scavenging enzymes, which play a significant role in the basal resistance to pathogens, are over-expressed in cecropin $A$ plants compared with wild-type plants. Most remarkable is the high level of expression of three different peroxidase genes in cecropin A plants. The observation that antioxidant systems are activated in transgenic plants in the absence of the pathogen is supported by the result that cecropin $A$ plants are tolerant to oxidative stress imposed by treatment with $\mathrm{H}_{2} \mathrm{O}_{2}$. Although cecropin A-mediated changes in the expression of endogenous rice genes are observed, this phenomenon may be beneficial to the host plant, as illustrated by the observed tolerance of transgenic plants to oxidative stress.

It is well known that peroxidases play a significant role in conferring resistance to both fungal and bacterial pathogens in Arabidopsis. As an example, transgenic Arabidopsis plants with reduced levels of expression of a peroxidase gene were more susceptible than wild-type plants to fungal and bacterial pathogens (Bindschedler et al., 2006). In wheat, over-expression of a peroxidase gene resulted in enhanced resistance to the powdery mildew fungus Blumeria graminis f. sp. tritici (Altpeter et al., 2005). As previously reported by our group, cecropin $A$ rice shows enhanced resistance to the rice blast fungus (Coca et al., 2006). In addition to this, cecropin $A$ plants have been shown to exhibit enhanced resistance to the bacterial pathogen Erwinia chrysanthemi, the causal agent of foot rot disease of rice (results not shown). This observation indicates that transgenic expression of the cecropin A gene in rice confers protection against fungal and bacterial pathogens. The increased level of expression of rice peroxidase genes in cecropin A plants relative to that in wild-type plants may enhance their resistance to pathogen infection, thus reinforcing the antimicrobial activity of cecropin $A$. If so, the resistance of cecropin A plants to pathogens may be the consequence of a combination of both the activity of cecropin $A$ and the activation of expression of endogenous defence genes.

Moreover, expression studies revealed that several ERresident chaperones taking part in the process of the folding and modification of polypeptides targeted for secretion were expressed at significantly higher levels in cecropin A plants than in wild-type plants. This was the case for the genes encoding calnexin, calreticulin, HSP90, DNAJ heat shock protein and PDI. In this respect, it is well known that plant cells monitor protein misfolding by triggering the synthesis and accumulation of stress-specific chaperones that bind temporarily to proteins (Federoff, 2006). Otherwise, the accumulation of misfolded proteins might become catastrophic, leading to cell death. Calreticulin/calnexin protein complexes act as molecular chaperones in the ER (Crofts and Denecke, 1998). The PDI protein not only has a chaperone function in the secretory pathway of proteins, but also participates in thiol disulphide interconversion in the ER. The rice HSP9O identified in our macroarray experiments shows a high degree of amino acid identity with two HSP9O proteins from barley and Madagascar periwinkle, for which an ER localization has been demonstrated (although the majority of cellular HSP90s are located in the cytoplasm, distinct organelle forms are found in the ER, plastid and mitochondria). Other genes that are over-expressed in cecropin A plants compared with wild-type plants are those encoding DNAJ heat shock proteins, which participate in the process of protein translocation into the ER and folding (Miernyk, 1999). It should be stressed that the transgenic cecropin $A$ rice lines used in this study express a cecropin $A$ gene engineered for retention of the cecropin A polypeptide in the ER (Coca et al., 2006). The results presented here on the subcellular fractionation of transgenic rice strongly suggest that cecropin A is indeed located in the ER. It is therefore reasonable to postulate that differences in gene expression between wildtype and cecropin A plants may be attributed to the site of accumulation of the transgene product: the ER. The high level of expression observed for genes involved in the folding and stabilization of proteins that enter into the secretory pathway in transgenic plants may reflect the need for an adjustment of chaperone levels in the ER, a response that 
resembles the so-called unfolded protein response for ERresident proteins. Therefore, the basal activity of the protein folding and stabilization machinery may not be sufficient to accommodate the level of cecropin A protein synthesis in transgenic rice plants, and these plants may need to maintain the machinery for the synthesis and folding of proteins in an activated state. This study provides strong evidence that the transgenic expression of an antimicrobial gene, the cecropin A gene, in rice has an impact on host gene expression.

Evidence was also provided that transgenic and wild-type plants share common responses to infection, as demonstrated by the type of genes induced in response to $M$. oryzae in both cecropin A and wild-type plants. A closer examination of the number and distribution of the fungal-induced genes in the functional categories, however, revealed some differences between cecropin $A$ and wild-type plants. Firstly, the number of fungal-responsive genes was significantly lower in cecropin A plants than in wild-type plants when using the same arbitrary twofold cut-off and at the same time after inoculation with fungal spores (94 and 162 unique genes were up-regulated by fungal infection in transgenic and wild-type plants, respectively). Secondly, the contribution of ESTs encoding defence genes in the overall response of transgenic plants to $M$. oryzae infection was lower than that in wild-type plants $(13.0 \%$ and $24.2 \%$ of the ESTs were grouped in the defence category in transgenic and wild-type plants, respectively; see Figures 1 and 6). The high level of expression of certain defence genes in cecropin $A$ plants under normal growth conditions, namely antioxidant systems, may account for the lower contribution of genes categorized in the defence group during the response of transgenic plants to infection. Together, these results indicate that, although expression of the cecropin A gene in transgenic rice does not impede the endogenous defence response, it exerts an effect on the transcriptional reprogramming that accompanies adaptation of the rice plant to infection conditions.

From the results obtained with cecropin A rice plants, it cannot be concluded that all transgenic plants must be considered to be 'not substantially equivalent' to wild-type plants at the level of gene expression. In other studies, transgenic wheat expressing a fungal phytase gene, or a highmolecular-weight glutelin subunit, exhibited only small differences in gene expression compared with untransformed plants (Gregersen et al., 2005; Baudo et al., 2006). Collectively, these data illustrate the need for the use of transcriptomics to explore the impact of transgene expression in plants, whilst establishing the need to approach these studies on a case-by-case basis. The availability of the rice defence gene collection obtained here provides an important tool for the analysis of gene expression in cultivated rice plants expressing other types of antimicrobial gene. A thorough understanding of the molecular mechanisms that operate in transgenic rice expressing antimicrobial genes, either during normal growth conditions or during interaction with the rice blast fungus, will undoubtedly aid in the evaluation of future strategies for the engineering of resistant rice cultivars using foreign antimicrobial genes.

\section{Experimental procedures}

\section{Plant material and infection conditions}

Rice (O. sativa L. Cv. Senia) plants were soil grown at $27 \pm 2{ }^{\circ} \mathrm{C}$ using a 18-h/6-h light/dark photoperiod. M. oryzae (PR9 isolate, CIRAD collection, Montpellier, France) was maintained on rice flour medium ( $20 \mathrm{~g} / \mathrm{L}$ rice flour, $15 \mathrm{~g} / \mathrm{L}$ agar and $2.5 \mathrm{~g} / \mathrm{L}$ yeast extract) until the mycelium covered the surface of the plate. Spores were collected by adding sterile water to the surface of the mycelium. After filtration, the spores were adjusted to the appropriate concentration with sterile water using a Bürker counting chamber. Infection of rice leaves with $M$. oryzae spores was performed using a detached leaf assay, as described previously (Coca et al., 2004). Briefly, the second leaf of 2-week-old soil-grown rice plants was placed into plate dishes with $1 \% \mathrm{w} / \mathrm{v}$ water agar containing $2 \mu \mathrm{g} / \mathrm{L}$ kinetine. Whatman filter paper saturated with an $M$. oryzae spore suspension at a concentration of $10^{6} \mathrm{spores} / \mathrm{mL}$ was placed on to the upper face of the leaf. The inoculated leaves were maintained in a chamber under humid conditions at $28^{\circ} \mathrm{C}$ using a $16-\mathrm{h} / 8$-h light/dark cycle for the required period of time.

\section{RNA isolation and Northern blot analysis}

Plant material was ground to a fine powder in liquid nitrogen using a mortar and pestle. Total RNA was extracted from rice leaves using TRIzol reagent (Invitrogen, Life Technologies, Basle, Switzerland). For Northern blot analysis, total RNAs $(10 \mu \mathrm{g})$ were subjected to $1.2 \%$ formaldehyde-containing agarose gel electrophoresis and transferred to nylon membranes (Hybond-N, Amersham, Little Chalfont, Buckinghamshire, UK). Hybridizations were carried out in $0.125 \mathrm{M}$ $\mathrm{Na}_{2} \mathrm{HPO}_{4} \mathrm{pH} 7.2,7 \%$ SDS, $1 \mathrm{~mm}$ ethylenediaminetetraacetic acid (EDTA), at $65^{\circ} \mathrm{C}$. Membranes were washed three times, $30 \mathrm{~min}$ each wash, in $0.02 \mathrm{M} \mathrm{Na}_{2} \mathrm{HPO}_{4} \mathrm{pH} 7.2,1 \mathrm{mM}$ EDTA and $1 \%$ SDS at $65^{\circ} \mathrm{C}$. All cDNA probes were gel purified and radioactively labelled by random priming.

\section{SSH and cDNA library construction}

The principle of PCR-selected CDNA subtraction (referred to as PCR-SSH) is to subtract, by hybridization, sequences that are shared between a control (or 'driver') sample and the sample of interest (or 'tester'), followed by the selective PCR amplification of the differentially expressed cDNAs. Thus, the SSH approach originally developed by Diatchenko et al. (1996), and subsequently improved by the ligation of generic linkers to CDNAs followed by PCR amplification and 
cloning of the differentially expressed cDNAs (PCR-SSH), allows a library to be normalized, thus minimizing clone redundancy. Thus, the cDNA subtraction method allows a cDNA library to be obtained which is enriched in sequences differentially represented between the two samples, making it easier to detect low-abundance transcripts than in the theoretically more optimal 'whole transcriptome' array. Moreover, the probes used for microarray preparation in global profiling studies are usually designed to interact with the $3^{\prime}$-regions of the targeted transcripts. Thus, it is possible that transcripts could be missed in global transcription profiling studies with the Senia variety using commercial rice arrays because of the poor hybridization between the probes and the labelled CDNA targets. Together, these aspects make the PCR-SSH technique, in combination with CDNA macroarray technology, especially suited for gene expression studies on the cultivated rice variety used in this investigation.

In this work, the PCR-SSH method was used to obtain a CDNA library representing different time points during the early response of rice to blast infection. Equal amounts $(100 \mu \mathrm{g})$ of total RNA from each infection time $(3,6,9,24$ and $48 \mathrm{~h}$ after inoculation with fungal spores) were combined prior to mRNA isolation. In each case, the starting biological material was a pool of leaves from at least six individual plants for each infection time. Equal quantities of total RNAs derived from control, non-infected leaves were also pooled. Poly $(A)^{+}$RNAs were purified using biotinylated oligo(dT) and streptavidin-coupled paramagnetic particles (PolyA-Tract System, Promega, Madison, WI, USA). Double-stranded CDNA was produced from $3 \mu \mathrm{g}$ of mRNA obtained from M. oryzae-infected (tester CDNA) or non-infected (driver CDNA) rice leaves. The SSH library was constructed following supplier instructions (Clontech, Palo Alto, CA, USA). The tester and driver CDNAs were digested with Rsal. The Rsal-digested tester cDNAs were ligated to different adapters (adapters 1 and 2). Two rounds of hybridization and PCR amplification were carried out to enrich the differentially expressed cDNAs. The SSH library enriched for differentially expressed cDNAs was constructed by ligating the subtracted cDNAs into the pGEM-Teasy vector (Promega) and transferring them into Escherichia coli $\mathrm{DH} 5 \alpha$. Individual recombinant bacterial colonies were picked and grown on 96-well microtitre plates.

\section{Amplification of cDNA inserts and cDNA macroarray preparation}

The cDNA inserts were amplified from colonies by PCR using adapter primers provided in the PCR-select CDNA subtraction kit, which were complementary to sequences flanking both sides of the CDNA insert. The PCRs contained $1.25 \mu \mathrm{L}$ of each primer ( $10 \mu \mathrm{M}$ each), $0.5 \mu \mathrm{L}$ deoxynucleoside triphosphate (dNTP) mix (10 mM each), $2.5 \mu \mathrm{L}$ $\mathrm{MgCl}_{2}(25 \mathrm{~mm}), 0.5 \mu \mathrm{L}$ of Taq DNA polymerase (Roche, Mannheim, Germany) and $1 \mu \mathrm{L}$ of bacterial culture in a total volume of $25 \mu \mathrm{L}$. PCRs were performed on a PTC-200 Peltier Thermal Cycler (MJ Research, Inc., Ramsey, Minnesota, USA) as follows: $94{ }^{\circ} \mathrm{C}$ for $5 \mathrm{~min}$, followed by 30 cycles of $94^{\circ} \mathrm{C}$ for $30 \mathrm{~s}, 68^{\circ} \mathrm{C}$ for $30 \mathrm{~s}$ and $72{ }^{\circ} \mathrm{C}$ for $2 \mathrm{~min}$, followed by a final extension step at $72^{\circ} \mathrm{C}$ for $7 \mathrm{~min}$. The PCR products were electrophoresed on a $0.8 \%$ agarose gel to confirm the amplification quality and quantity.

The PCR products were transferred to 384-well plates. The BioGrid Robotic System (BioRobotics, Cambridge, UK) with a 384 gridding tool (diameter, $0.4 \mathrm{~mm}$ ) was used to spot cDNAs on to nylon membranes (Hybond $\mathrm{N}+$, little Chalfont, Buckinghamshire, UK). Each clone was spotted 10 times on to the membrane (about $0.2 \mu \mathrm{L}$ per spot) with a spot diameter of $0.6 \mathrm{~mm}$. The membranes were kept humid by setting them on to three Hybond ${ }^{\mathrm{TM}}$ blotting paper sheets soaked in denaturing solution $(1.5 \mathrm{M} \mathrm{NaCl}, 0.5 \mathrm{M} \mathrm{NaOH})$. After printing, the membrane was neutralized with $1.5 \mathrm{M} \mathrm{NaCl}, 0.5 \mathrm{M}$ Tris $/ \mathrm{HCl} \mathrm{pH} 7.2$, $1 \mathrm{~mm}$ EDTA pH 8.0 for $1 \mathrm{~min}$. No subsequent UV fixation was necessary, and the membranes were kept on filter paper until completely dry.

In addition to the CDNA rice inserts, the PGEM-T plasmid DNA was spotted on to each membrane as a negative control. Known rice defence genes, namely those encoding $\beta$-1,3-glucanase (accession number AB027432), two chitinases (accession numbers X56063 and AB016497), OsPR 10 (accession number AF395880) and thionin (accession number AB072337), and EcoRI-digested rice genomic DNA, were also printed on the membrane to serve as internal positive controls. The rice genomic DNA was extracted from 4-weekold rice leaves according to the method of Murray and Thompson (1980), but using mixed alkyltrimethylammonium bromide (MATAB) as the extraction buffer $(0.1 \mathrm{M}$ Tris/ $\mathrm{HCl} \mathrm{pH} 8.0,1.4 \mathrm{M} \mathrm{NaCl}, 20 \mathrm{~mm}$ EDTA, 2\% MATAB, 1\% PEG6000, 0.5\% sodium sulphite).

\section{Macroarray hybridization, scanning and data analysis}

As a control test for printing quality, hybridization with genomic DNA from $M$. oryzae was performed, which was obtained by growing the fungus on a rice flour liquid medium $(500 \mathrm{~mL})$ for 1 month, with the mycelium harvested from the liquid culture by filtration. M. oryzae genomic DNA was extracted as described above. The $M$. oryzae genomic DNA ( $1 \mu \mathrm{g})$ was digested with EcoRI, radioactively labelled by random priming (Roche) and used as hybridization probe.

Total RNAs were obtained from rice leaves inoculated with $M$. oryzae and control leaves. Rice CDNAs were obtained by reverse transcription from $40 \mu \mathrm{g}$ of total RNA and labelled with ${ }^{33} \mathrm{P}-\alpha-$ deoxycytidine triphosphate (dCTP) using SuperScript II Reverse Transcriptase (Invitrogen), as described previously (Alberola et al., 2004). Total RNA was also isolated from leaves of 2 -week-old cecropin A plants (lines R33-24.3, R33-33.7 and R33-6.3, with 10 plants per line), as well as from leaves from wild-type plants at the same developmental stage. The labelled cDNA probes were denatured at $100{ }^{\circ} \mathrm{C}$ for $5 \mathrm{~min}$, followed by $5 \mathrm{~min}$ on ice, and then used for hybridization. Before hybridization, the membranes were washed in $0.5 \%$ SDS for $30 \mathrm{~min}$ at $80^{\circ} \mathrm{C}$. The membranes were pre-hybridized in $5 \mathrm{~mL}$ of $5 \times$ standard saline citrate (SSC), $0.5 \%$ SDS, $5 \times$ Denhart's solution at $65^{\circ} \mathrm{C}$ for at least $1 \mathrm{~h}$. Hybridization was carried out by adding the denatured probe to fresh hybridization solution $\left(5 \times 10^{6} \mathrm{dpm} / \mathrm{mL}\right)$ for $40-64 \mathrm{~h}$ at $60^{\circ} \mathrm{C}$. After hybridization, the membranes were washed at $65^{\circ} \mathrm{C}$ in $2 \times$ SSC, $0.1 \%$ SDS for $20 \mathrm{~min}$, and twice in $0.2 \times$ SSC, $0.1 \%$ SDS for $30 \mathrm{~min}$. Two replica membranes were hybridized with each ${ }^{33} \mathrm{P}$-labelled cDNA population.

Hybridization signals were recorded by phosphorimaging (FujiFilm FLA3000 Phosphorimager, Berlin, Germany). The image data obtained were imported into the software program ArrayVision 7.0 (Imaging Research, St. Catharines, ON, Canada) for spot detection and quantification of hybridization signals. Backgrounds were subtracted using ArrayVision 7.0 to obtain raw signal intensities. To assess the reproducibility of the macroarray analysis, two independent hybridizations were conducted for each condition. To control against biological errors, hybridizations were performed with replica membranes for two independently labelled cDNAs from RNA samples obtained 
from two independently pooled leaf samples. Data for the expression analysis were averages of the two independent experiments. The nucleotide sequences of the selected cDNAs were determined and compared with nucleotide and protein sequence databases (GeNBANK, http://www.ncbi.nlm.nih.gov; KOME, http:// cdna01.dna.affrc.go.jp; MGOS, http://www.mgosdb.org).

\section{RT-PCR and qRT-PCR analyses}

For RT-PCR and qRT-PCR analyses of the rice defence genes, total RNA was extracted from leaves of rice plants at the three- to four-leaf stage at different times after fungal inoculation with fungal spores. For each time point, leaves were collected from 10 individual plants. Total RNA was treated with DNase I (Roche) to remove DNA contamination before CDNA synthesis. The CDNA was synthesized from $5 \mu \mathrm{g}$ of total RNA using $500 \mathrm{ng}$ of oligo(dT) $)_{12-18}$ in a total volume of $20 \mu \mathrm{L}$. Aliquots ( $1 \mu \mathrm{L}$ of a $1: 10$ dilution of the resulting $R T$ reaction product) were used as template for RT-PCR analysis.

The primers used for RT-PCR analysis were as follows: Rgp 1 (forward, 5'-GAGTTAAGAGGCCATGCTGACAAGAA-3'; reverse, 5'-CAGTGTTGATATGGCAGGAGTAAACT-3'); GAP (forward, 5'GCAACTGAACATGGTAGCCAGGATAA-3'; reverse, 5'-CACTACTC AATCCTACCGTGAAGGGT-3'); profilin (forward, 5'-GGAGATTAC TGGCATCATGAAGGACT-3'; reverse, 5'-GTACAGAACTCAGT GAATGGACAGCT-3'); TRAPP-Bet3 (forward, 5'-GCTGACTCACTTG AGAAAGGAACAGA-3'; reverse, 5'-GTACACAAATCATGTGGAGTC AGC(A- $\left.3^{\prime}\right)$. The control of the rice ubiquitin 1 gene was performed using the primers: forward, 5'-CGCCTTCTCAAGATGCAGATCTT-3'; reverse, 5'-CTGGATGTTGTAGTCAGCAAGGGT-3'.

The forward and reverse primers for qRT-PCR were designed using the PrimerXpress program (Applied Biosystems, Foster City, CA, USA). They were as follows: EREBP (forward, 5'-TGTTGGAGACTGATTCAAATAATGC-3'; reverse, 5'-CACATTACAGCACACACATGGC-3'); elF5A-4 (forward, 5'-CCCCTAAACCACCATCCCTAG-3'; reverse, 5'-AATGATATTTTCACCTTAAGCACACAAT-3'); HSP9O (forward, 5'-GGAGCCGTCGTCGTATGATAA-3'; reverse, 5'-TTGGTGGCGACACATCACTAC- $3^{\prime}$ ). A set of primers for the rice actin 1 (Rac1) gene was also designed for use as an endogenous control to normalize the data for differences in input RNA and efficiency of reverse transcription (forward, 5'-CСTCTTCCAGCCTTCCTCATA-3'; reverse, 5'-GCAATGCCAGGGAACATAGTG-3').

qRT-PCR analysis was performed in optical 96-well plates using SYBRGreen to monitor double-stranded DNA synthesis (Platinum SYBRGreen $\mathrm{qPCR}$ with ROX, Invitrogen). Each reaction contained $2 \mu \mathrm{L}$ of a $1: 100$ dilution of CDNA and $300 \mathrm{nM}$ of each of the two gene-specific primers in a final volume of $20 \mu \mathrm{L}$. PCR was performed on an AbiPrism 7000 instrument (Applied Biosystems). After the initial activation step of the DNA polymerase at $95{ }^{\circ} \mathrm{C}$ for $2 \mathrm{~min}$, samples were subjected to 40 cycles of amplification (denaturation at $95^{\circ} \mathrm{C}$ for $15 \mathrm{~s}$, annealing and extension together at $60{ }^{\circ} \mathrm{C}$ for $30 \mathrm{~s}$ ). No RT controls were included in the PCR runs to ensure negligible contamination of total RNA samples with genomic DNA.

Quantification of target gene expression was performed using the comparative threshold cycle $\left(C_{T}\right)$ method. The $C_{T}$ value is defined as the PCR cycle number that crosses an arbitrarily chosen signal threshold in the logarithmic phase of the amplification curve. Primer validation experiments were performed using $2 \mu \mathrm{L}$ of fivefold dilutions of $c D N A$. The average $C_{T}$ values from triplicate PCRs were normalized to the average $C_{T}$ values for the actin gene from the same cDNA preparations. For each gene, normalized transcript levels in $M$. oryzae-infected leaves were compared with those of the respective control leaves.

\section{Subcellular fractionation}

Leaves from wild-type and transgenic plants were pulverized and homogenized in PBP buffer $(0.1 \mathrm{M}$ Tris $/ \mathrm{HCl} \mathrm{pH} \mathrm{8.0,0.05} \mathrm{M} \mathrm{KCl,}$ $0.01 \mathrm{M} \mathrm{MgCl}_{2}, 2 \mathrm{mM}$ EDTA, containing $10 \%$ sucrose; $0.025 \mathrm{~g}$ fresh weight per millilitre) for $15 \mathrm{~min}$ at $4{ }^{\circ} \mathrm{C}$ with slow stirring. The homogenate was filtered through two layers of miracloth to remove cellular debris. Three millilitres of the filtrate were loaded on to a discontinuous sucrose gradient $(20 \%, 30 \%, 40 \%, 50 \%$ and $70 \%$ sucrose in PBP buffer, $2 \mathrm{~mL}$ each) and centrifuged at $24000 \boldsymbol{g}$ for $2 \mathrm{~h}$ at $4{ }^{\circ} \mathrm{C}$ using a Beckman SW40 rotor (Beckman, Muskegon, MI, USA). Then, 1-mL fractions were collected and subjected to immunoblot analysis. The fractionation profiles of cecropin $A$ and the ER marker BiP protein were examined. For this, a polyclonal antibody raised in rabbit against cecropin A (Coca et al., 2006) and BiP (kindly provided by M.D. Ludevid and M. Torrent) were used. Blots were incubated for $2 \mathrm{~h}$ at room temperature with anti-cecropin $\mathrm{A}$ or the anti-BiP protein (diluted $1: 500$ and $1: 2000$, respectively), followed by incubation with a secondary antibody conjugated with horseradish peroxidase and detection by the ECL system (Amersham Bioscience, Braunschweig, Germany).

\section{NBT staining for $\mathrm{O}_{2}^{-}$}

For histochemical detection of $\mathrm{O}_{2}^{-}$, leaf sections of approximately $2 \mathrm{~cm}$ in length were excised from either transgenic or wild-type plants and stained with NBT, as described by Fitzgerald et al. (2004).

\section{Acknowledgements}

S.C. and S.M. were recipients of a predoctoral fellowship from the Ministerio de Educación y Ciencia (MEC). We are grateful to M.D. Ludevid and M. Torrent for the anti-BiP antiserum and valuable help with the subcellular fractionation experiments, and to P. Fontanet for taking care of the glasshouse-grown plants. This work was funded by grant BIO2006-05583 from MEC and within the Centre CONSOLIDER on Agrigenomics and the Xarxa de Referencia en Biotecnología (Generalitat de Catalunya).

\section{References}

Alberola, T.M., García-Martínez, J., Antúnez, O., Viladevall, L., Barceló, A., Ariño, J. and Pérez-Ortín, J.E. (2004) A new set of DNA macrochips for the yeast Saccharomyces cerevisiae: features and uses. Int. Microbiol. 7, 199-206.

Altpeter, F., Varshney, A., Abderhalden, O., Douchkov, D., Sautter, C., Kumlehn, J., Dudler, R. and Schweizer, P. (2005) Stable expression of a defense-related gene in wheat epidermis under transcriptional control of a novel promoter confers pathogen resistance. Plant Mol. Biol. 57, 271-283. 
Aparicio-Fabre, R., Guillen, G., Estrada, G., Olivares-Grajales, J., Gurrola, G. and Sanchez, F. (2006) Profilin tyrosine phosphorylation in poly-L-proline-binding regions inhibits binding to phosphoinositide 3-kinase in Phaseolus vulgaris. Plant J. 47, 491-500.

Baudo, M.M., Lyons, R., Powers, S., Pastori, G.M., Edwards, K.J., Holdsworth, M.J. and Shewry, P.R. (2006) Transgenesis has less impact on the transcriptome of wheat grain than conventional breeding. Plant Biotechnol. J. 4, 369-380.

Berrocal-Lobo, M., Molina, A. and Solano, R. (2002) Constitutive expression of ETHYLENE-RESPONSE-FACTOR1 in Arabidopsis confers resistance to several necrotrophic fungi. Plant J. 29, 2332.

Bhat, R.A. and Panstruga, R. (2005) Lipid rafts in plants. Planta, 223, 5-19.

Bindschedler, L.V., Dewdney, J., Blee, K.A., Stone, J.M., Asai, T., Plotnikov, J., Denoux, C., Hayes, T., Gerrish, C., Davies, D.R., Ausubel, F.M. and Paul Bolwell, G. (2006) Peroxidase-dependent apoplastic oxidative burst in Arabidopsis required for pathogen resistance. Plant J. 47, 851-863.

Borner, G.H.H., Sherrier, D.J., Weimar, T., Michaelson, L.V., Hawkins, N.D., MacAskill, A., Napier, J.S., Beale, N.H., Lilley, K.S. and Dupree, P. (2005) Analysis of detergent-resistant membranes in Arabidopsis. Evidence for plasma membrane lipid rafts. Plant Physiol. 137, 104-116.

Broglie, K., Chet, I., Holliday, M., Cressman, R., Riddle, P., Knowlton, S., Mauvais, C.J. and Broglie, R. (1991) Transgenic plants with enhanced resistance to the fungal pathogen Rhizoctonia solani. Science, 254, 1194-1197.

Campo, S., Carrascal, M., Coca, M., Abián, J. and San Segundo, B. (2004) The defense response of germinating maize embryos against fungal infection: a proteomics approach. Proteomics, 4, 383-396.

Coca, M., Bortolotti, C., Rufat, M., Peñas, G., Eritja, R., Tharreau, D., Martínez del Pozo, A., Messeguer, J. and San Segundo, B. (2004) Transgenic rice plants expressing the antifungal AFP protein from Aspergillus giganteus show enhanced resistance to the rice blast fungus Magnaporthe grisea. Plant Mol. Biol. 54, 245-259.

Coca, M., Peñas, G., Gómez, J., Campo, S., Bortolotti, C., Messeguer, J. and San Segundo, B. (2006) Enhanced resistance to the rice blast fungus Magnaporthe grisea conferred by expression of a cecropin A gene in transgenic rice. Planta, 223, 392-406.

Crofts, A.J. and Denecke, J. (1998) Calreticulin and calnexin in plants. Trends Plant Sci. 3, 396-399.

Danon, A., Rotari, V.I., Gordon, A., Mailhac, N. and Gallois, P. (2004) Ultraviolet-C overexposure induces programmed cell death in Arabidopsis, which is mediated by caspase-like activities and which can be suppressed by caspase inhibitors, p35 and Defender Against Apoptotic Death. J. Biol. Chem. 279, 779-787.

Datta, S., Muthukrishnan, S. and Datta, S.K. (1999) Expression and function of PR proteins in transgenic plants. In: Pathogenesis-Related Proteins in Plants (Datta, S.K. and Muthukrishnan, S., eds), pp. 261-277. New York: CRC Press.

Diatchenko, L., Lau, Y.F., Campbell, A.P., Chenchik, A., Moqadam, F., Huang, B., Lukyanov, S., Lukyanov, K., Gurskaya, N., Sverdlov, E.D. and Siebert, P.D. (1996) Suppression subtractive hybridization: a method for generating differentially regulated or tissue-specific CDNA probes and libraries. Proc. Natl. Acad. Sci. USA, 93, 60256030.

Duttaroy, A., Bourbeau, D., Wang, X.L. and Wang, E. (1998) Apoptosis rate can be accelerated or decelerated by overexpres- sion or reduction of the level of elongation factor-1 alpha. Exp. Cell Res. 238, 168-176.

El Ouakfaoui, S. and Miki, B. (2005) The stability of the Arabidopsis transcriptome in transgenic plants expressing the marker genes nptll and uidA. Plant J. 41, 791-800.

Emani, C., Garcia, J.M., Lopata-Finch, E., Pozo, M.J., Uribe, P., Kim, D.J., Sunilkumar, G., Cook, D.R., Kenerley, C.M. and Rathore, K.S. (2003) Enhanced fungal resistance in transgenic cotton expressing an endochitinase gene from Trichoderma virens. Plant Biotechnol. J. 1, 321-336.

Federoff, N. (2006) Redox regulatory mechanisms in cellular stress responses. Ann. Bot. 98, 289-300.

Fitzgerald, H.A., Chern, M.S., Navarre, R. and Ronald, P.C. (2004) Overexpression of (At) NPR1 in rice leads to a BTH- and environmentinduced lesion-mimic/cell death phenotype. Mol. Plant-Microbe Interact. 17, 140-151.

Gregersen, P.L., Brinch-Pedersen, H. and Holm, P.B. (2005) A microarray-based comparative analysis of gene expression profiles during grain development in transgenic and wild type wheat. Transgenic Res. 14 (6), 887-905.

Gutterson, N. and Reuber, T.L. (2004) Regulation of disease resistance pathways by AP2/ERF transcription factors. Curr. Opin. Plant Biol. 7, 465-471.

Jurgens. G. (2004) Membrane trafficking in plants. Annu. Rev. Cell. Dev. Biol. 20, 481-504.

Kim, S., Ahn, I.-P. and Lee, Y.-H. (2001) Analysis of genes expressed during rice-Magnaporthe grisea interactions. Mol. Plant-Microbe Interact. 14, 1340-1346.

Lamb, C. and Dixon, R.A. (1997) The oxidative burst in plant disease resistance response. Annu. Rev. Plant Physiol. Plant Mol. Biol. 48, 251-275.

van Loon, L.C., Rep, M. and Pieterse, C.M.J. (2006) Significance of inducible defense-related proteins in infected plants. Annu. Rev. Phytopathol. 44, 135-162.

Lorito, M., Woo, S.L., García-Fernandez, I., Colucci, G., Harman, G.E., Pintor-Toro, J.A., Filippone, E., Muccifora, S., Lawrence, C.B., Zoina, A., Tuzun, S. and Scala, F. (1998) Genes from mycoparasitic fungi as a source for improving plant resistance to fungal pathogens. Proc. Natl. Acad. Sci. USA, 95, 7860-7865.

Lu, G., Jantasuriyarat, C., Zhou, B. and Wang, G.-L. (2004) Isolation and characterization of novel defense response genes involved in compatible and incompatible interactions between rice and Magnaporthe grisea. Theor. Appl. Genet. 108, 525-534.

de las Mercedes Dana, M., Pintor-Toro, J.A. and Cubero, B. (2006) Transgenic tobacco plants overexpressing chitinases of fungal origin show enhanced resistance to biotic and abiotic stress agents. Plant Physiol. 42, 722-730.

Miernyk, J.A. (1999) Protein folding in the plant cell. Plant Physiol. 121, 695-703.

Mongrand, S., Morel, J., Laroche, J., Claverol, S., Carde, J.P., Hartmann, M.A., Bonneu, M., Simon-Plas, F., Lessire, R. and Bessoule, J.J. (2004) Lipid rafts in higher plant cells: purification and characterization of Triton X-100-insoluble microdomains from tobacco plasma membrane. J. Biol. Chem. 279, 36 27736286.

Murray, M.G. and Thompson, W.F. (1980) Rapid isolation of high molecular weight plant DNA. Nucleic Acids Res. 8, 4321-4325.

Ou, S.H. (1985) Rice Diseases, 2nd edn. Kew, Surrey: Commonwealth Mycological Institute.

Rauyaree, P., Choi, W., Fang, E., Blackmon, B. and Dean, R.A. (2001) 
Genes expressed during early stages of rice infection with the rice blast fungus Magnaporthe grisea. Mol. Plant Pathol. 2, 347-354.

Reymond, P., Weber, H., Damond, M. and Farmer, E.E. (2000) Differential gene expression in response to mechanical wounding and insect feeding in Arabidopsis. Plant Cell, 12, $707-$ 720.

Talbot, N.J. (2003) On the trail of a cereal killer: exploring the biology of Magnaporthe grisea. Annu. Rev. Microbiol. 57, 177-202.
Wick, P., Gansel, X., Oulevey, C., Page, V., Studer, I., Durst, M. and Sticher, L. (2003) The expression of the t-SNARE AtSNAP33 is induced by pathogens and mechanical stimulation. Plant Physiol. 132, 343-351.

Xiong, L., Lee, M.-W., Qi, M. and Yang, Y. (2001) Identification of defense-related rice genes by suppression subtractive hybridization and differential screening. Mol. Plant-Microbe Interact. 14, 685-692. 